\title{
STUDIES ON THE HEALING PROCESS OF OPERATED TEMPORAL BONE OF CHRONIC OTITIS MEDIA
}

\author{
By \\ H. NISHIHATA \\ From the Department of Otorhinolaryngology, School of Medicine, Keio University. \\ (Director: Prof. T. Nishihata)
}

The author made a statistical observation in 122 cases of chronic otitis media treated by the radical mastoidectomy. Complete wound healing was seen in $62.3 \%$ of the total number cases. Among those with incomplete wound healing, the difficulty was seen in window niche in $37.0 \%$, at the orifice of the eustachian tube in $28.2 \%$, in hypotympanum in $23.9 \%$, in promontorium in $8.7 \%$, in perilabyrinth or sinodural angle in $8.7 \%$, in retrofacial area in $6.5 \%$, in attic $4.3 \%$ and in perisinous area in $2.2 \%$.

In 49 cases reoperated, the pathology was found to be seen in the cells and mucosa in most of the cases. In 15 cases of which numbers the result of the operation appeared to be satisfactory at first but no complete healing could be established. Microscopic examination of these cases revealed the failure of healing to be the presense of pathological mucosa that interfered with proper epidermization.

Morphologically, the pathological mucosa was classified into 9 different types. The most conspicuous change was the infolding of the mucosa and cyst formation. The cyst has also been observed beneath the epidermis where the clinical healing for a period of time had been satisfactory.

It is impossible to remove the mucosa completely during the opration, nor is it possible to prevent extension outgrowth of the tubal mucosa, the healing of this area is necessarily epidermization superimposing the impreventable mucous membrane which when examined microscopically will show cyst formation and air cavity, the proximal end of the eustachian tube.

The pathological bone does not always interrupt the epidermization.

The author could find one tympanic gland out of all cases. This one was a single tubal gland and it's blind end tended to form a cyst.

\section{慢性中耳炎根治手術創の治瘾機転に関する研究}

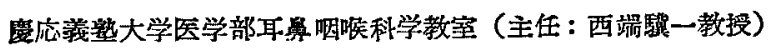

$$
\text { 助手西端公公郎 }
$$

\section{目次}

I 緒言及び斫究目的

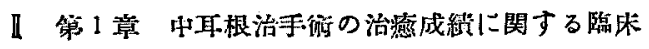
的観察

1. 研究村料

2. 手衍方法並びに後処直

3. 治港绑定方法

4. 研究成績

1) 治 缹 济

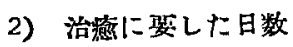

3）嚁治部位の統棓学的㘥察

4）耳管入口部の処㯰による相造

5）遠隔成綪

5. 交擜的栲察及び考掉

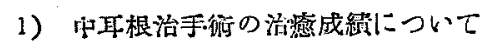

2) 衡創の難沿部位について

3）耳管の開邀について

4) 植皮につけて

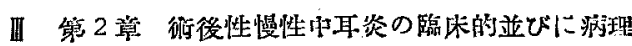
組織学的研究 
1. 緒霄

2. 研究村料と之の分析

3. 臨䢶的钼察

1）前手行が所謂乳様突廵㓩開街及び聴保根治 手䘗であつた群について

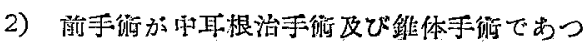
た群について

4. 病理組織学的研究

1) 研究材料と方法

2) 研觉成綕

3）润理組織学的所見の小括

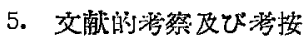

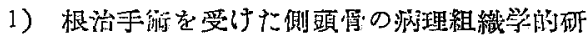
究について

2）根治手衡㓱の治撚状熊並びにをの再発につ WT

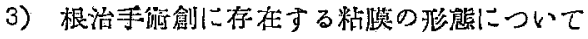

4）战茈凹陷について

5) 粘膜テステについて

6) 腺夫ステについて

7）筒変化の意笔について

N 結 需

V 召有交献

\section{I 緒言及び研究目的}

慢性中耳炎に対する根治手術の意義は，Stacke，Zaufal (1890) 以来今日迄の間に若千の变遷を経た。

即ら，Stacke の云ら“生命に危険のある，又は将来 危険のある中耳化膿の除去”（Mayer ${ }^{31)}$ の网用による） のために行われた根治手術が，化学潦法を中心とした医 学の進歩によつて, Lempert 26) (1950) の言うように, その目的を頭蓋肉合併症の予防から完全な耳漏の停止と いら方向に主眼が向けられ，近年では聴力改善の見地か ら根治手術の再検討が行われらつある事は周知の通りで ある・

しかし，現在に和いても根治手術（錐体手術を含め て）による耳漏の停止といら目的は必ずしも完全に達せ られたとは云い得ない。

根治手術によつてむ治り難い原因に就ては，古来幾多 の報告があるが，最も重要視されたのは耳管の問題であ る. 根治手術に怙ける耳管の意義については Siebenmann (1893) 以来 Reinking (4), Lange 22), Wittmaack 55), Laurowitsch 24) らを始めとし枚举にいとまのない 程の報告が放り，根治手術の治癒成綪についての報告い
殖ど耳管との閶連について論求られている・そして耳管

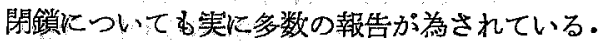

-一片，Zeroni 58) (1898) が根治手術のかなり 充分に 行われた側頭骨について，鼓室後方の嚾かな病巣部に遺 残粘膜を証明して以来, Reinking 44), Ruttin ${ }^{45)}$, Lan-

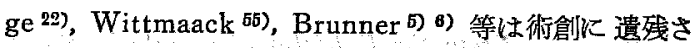
れた粘膜が表皮化を妨げる重要な因子である事を臨床的 に病理学的立埸加５強調した。

及 Mann 27) (1912) が根治手術後の 術創に和いて耳 管周囲䗋采か゚耳管入口部の治噔を妨げる重要な因子であ る事を主張 したが，我国でる近年錐体蜂栄が重要視さ

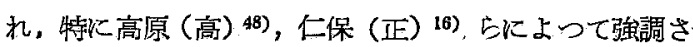
れてきた。

その他表皮化を始げる原因として，骨病変の意義を重 視するものに Krebs 21) (1912), Mann 27) (1912), Ne-

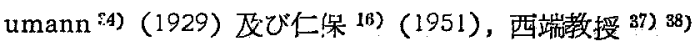
(1952) 等の報告がある。

㕛臨床的立場加ら，術後再感染，後療法の不適当を重 視するむのは Neumann 34) (1929), Mayer 31) (1929), Withalm ${ }^{\text {(4) }}$ (1955), 堀口 ${ }^{15)}$ (1955), Rambo ${ }^{42)}$ (1956), Ohrt 39) (1957) 等である.

以上のように根治手術によつても治泳し難、原因につ いては，古来多くの報告があるが今日な和不明の点が少 くないしが，それには多くの複雑な因子が関与して いると考它られるので，その究明な容易な事ではないと 思われる。

そこで私は一つの方法として，

1. 根治手術を行つた患者について，術創のいかなる

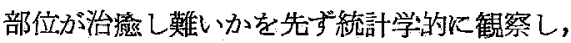

2. 根治手術を行つて子治り難い症例（これを術後性 慢性中耳炎と称する）について，その病亲部を病理組瀻 学的検索し，

3.これらの病亲部を取除くと，果してどのような治 癒過程をとるものかを観察した：

この問題について采統的に研究した報告は見当らない ので，私以上上の方法を的つて本砄究を行い一店の知見 を得たと思らのでこ」に報告する次第である。

\section{II 第1章 中耳根治手術の治虑成績に関する}

\section{咟床的観察}

\section{1. 研究材 料}

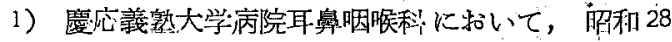
年 1 月から33 年3月迄の間に中耳根治手術を行つたも の〉内，比較的観察が充分行われた112 例を選んだ. 


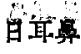

2) 性別
男

女

3）年令
64 例

48 例

$\begin{array}{rr}5 \sim 10 \text { 才 } & 3 \text { 例 } \\ 11 \sim 20 \text { 才 } & 46 \text { 例 } \\ 21 \sim 30 \text { 才 } & 43 \text { 例 } \\ 31 \sim 40 \text { 才 } & 11 \text { 例 } \\ 41 \sim 50 \text { 才 } & 5 \text { 例 } \\ 51 \text { 才以上 } & 4 \text { 例 } \\ & 112 \text { 例 }\end{array}$

4）112 例中 10 例は上記期間中に再手術を行つてい るので，手術例数は 122 例である。その内再手術例はこ の 10 例を含めて 49 例ある.

5）遠滆成績として，112 例に知して昭和 33 年 6 月 現在に和いて，主として耳漏の有奥についてアンケート を求めた・その内直接診察する事ができたるのは59.例 で，返信のみのものは18 例であつた，即ち，遠滆成績

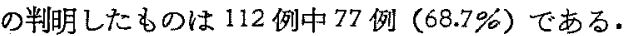

\section{2. 手術方法並ひに後処置}

122 手術例中 6 例を涂き手術は私が行い，又術後処置 及び観察は全例私が行つた。

全例とも耳後法により根治手術を行つた・鼓至近置 は，外耳道底及び前壁を広く削開し，明視下に下鼓音， 耳管周囲を掻爬した。耳管周囲の撜爬は，主として耳管 入口部のみを䗗爬したものと，更に進んで頸動脈管を管 出し周囲蜂栄を徹底的に搔爬，即ち Mayer 法を行つた ものとがある.

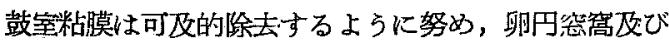

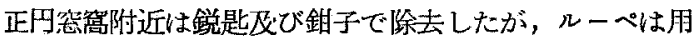
いなからた，愦つて鐙骨を除去したものは 2 例ある。

全例とも術後淔ちに全創面人一次植皮を行つた。植皮 片は鈴末，川鳴 47) (1953) の発表した方法により，耳後 毛髮部から採取した。

後処置として術後 1 2 週間サルフア剂附服，ベニシ リン注射又はクロラムフエニュール立服を行つた。

術後5〜7日で全ガーゼを交換し，以後毎日ダンボン 交換を行い，主ししてペニシリン及び 10\% 水モスルフ アミン液の混合液を $2 \sim 4 \mathrm{cc}$ 注入した・症例によつては マイシリン溶液，コリステン溶液又はクロラムフェニコ ール点耳液を朋いたものもある・分速が娍少すれば乾が

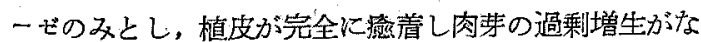
ければ，無タンポン硼酸卡撒存に移行した。

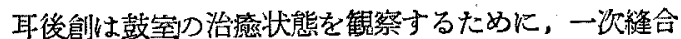

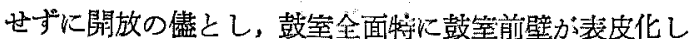
乾懆した事を確認して後始めて Passow 法により整形 開鎖するのを原則とした，完全に表皮化しないものは止 むを得ず，ほ心゙治猃機転が停止固定したと思われた时に 耳後創を閉鎖した。

\section{3. 治磨判定方法}

術創全面が表皮によつて完全に被われ，乾燥したもの を完全治癒とした，一部分表皮化世ぬものは不完全治㴔 とし，これ等を乾燥しているもの，分泌のあるものとに 分けた。

往来我国では一般に，術創が表皮によつて被われるこ とを上皮化 (Epitherisierung) と称しているが, 術創の 治癋過程を理解するには，表皮の伸展と粘膜上皮の伸展 とを䈌密に区別する事が必要であると思うので，私は本

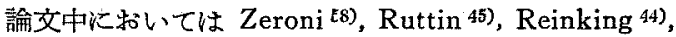
Lange 22) 23), Wittmaack 55), Mayer 31) 等の記載になら つて，角化性重貣扁平上皮の伸展を表皮化（Epidermisierung)，粘膜上皮の牦展支上皮(Epitherisierung) と呼 称し，両者を厳泌に区別して用らる事にした。

\section{4. 研究成績}
（1）治满率（122 手術例中）
完全治㷰
76 例
$62.3 \%$
不完全治浗
46 例
$37.7 \%$

(2) 治瘾心要した日数

治痩した76 例の 完全表皮化迄の日数は第 1 表に示し た。但し耳後整形のための日数を含まない。最短 16 日， 最長 10 月で，大部分は 1〜2 月で完全に表皮化した。

第 1 表

$\begin{array}{ll}1 / 2 \text { 月以 } & 0 \text { 例 } \\ 1 / 2 \sim 1 \text { 月 } & 16 \text { 例 }(21.1 \%) \\ 1 \sim 1 / 2 \text { 月 } & 22 \text { 例 }(28.9 \%) \\ 11 / 2 \sim 2 \text { 月 } & 19 \text { 例 }(25.0 \%) \\ 2 \sim 3 \text { 月 } & 6 \text { 例 }(7.9 \%) \\ 3 \sim 4 \text { 月 } & 5 \text { 例 }(6.6 \%) \\ 4 \sim 5 \text { 月 } & 2 \text { 例 }(2.6 \%) \\ 5 \sim 6 \text { 月 } & 2 \text { 例 }(2.6 \%) \\ 6 \text { 月 1 年 } & 4 \text { 例 } \\ 1 \text { 年以上 上 } & 0 \text { 例 }\end{array}$

(3) 難治部位の統計学的観察

表皮化しなかつた 46 例 (37.7\%) について，その表 皮化しない部位は第 2 表の通りである。

2 個所表皮化しないものが9例あり，内1例鼓案後

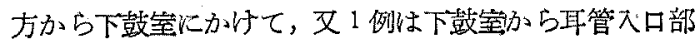
にかけて連続した病巣を呈していた。 
第 2 表

\begin{tabular}{|c|c|c|c|c|}
\hline 新 & 例敕 & & F炡 & 分证 \\
\hline 闌新 & 3 & (46例中 $6.5 \%$ ) & 2 & t \\
\hline 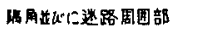 & 4 & $(8.7 \%)$ & 0 & 4 \\
\hline S些洞固圆部 & 1 & $(2.2 \%)$ & 0 & 1 \\
\hline 上错宝 & 2 & $(4.3 \%)$ & 0 & 2 \\
\hline 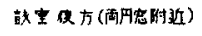 & 17 & $(37.0 \%)$ & 4 & 13 \\
\hline F期豈 & 11 & $(23.9 \%)$ & 2 & 9 \\
\hline 耳安入口部 & 13 & $(28.2 \%)$ & $t$ & 12 \\
\hline \multirow[t]{2}{*}{ 欺宔全体 } & 4 & $(8.7 \%)$ & 0 & 4 \\
\hline & 55 & & $g$ & 46 \\
\hline
\end{tabular}

鼓室全体が表皮化しないのは Grunert 31) 44)，Lange 22), Wittmaack ${ }^{55), ~ L a u r o w i t s c h ~}{ }^{24)}$ らの云うように, 耳管が開口して耳管粘膜が伸展し，鼓䆓が再び粘膜上皮 によつて上皮化されたるのであつて，耳管入口部の未治 例に含まれるべきものと考えられる。

又乳突部の治つていない8例についてみると（迷路周 国蜂栄は錐体であるが，臨床的観察の便宜上乳突部に含 めた。以下同様）鼓室の治っているすのは 3 例で，他の 5 例は鼓室にも末治部位を有している・即ち 未治例 46 例中鼓室の治っているるのは3例に過ぎない。

以上の結果から，表皮化しない部位は乳突部の $14.6 \%$ に比して，鼓至交び鼓室周辺部が $85.4 \%$ 王倒的に多い 事が分る。

鼓室及び鼓室周辺部の内でる，鼓室後方即ち正卵両円 空附近及び耳管入口部が最多く，㳄に下鼓堂が多い。

云う迄むなく、これ等は手術的操作を加える事が最も 困難な部位である・換言すれば，手術によつてる表皮化 乙難い部位は病的粘膜を宗全に搔爬除去し得ない部位が 压倒的红多い。

\section{（4）耳管人口部の処置による相違}

前述のように主として耳管入口部のみを播爬したもの （56 例）之，更に徹底して頸﨡脈管を露出して Mayer 法を行つたもの（62 例）に分け，前者を単純耳管搔爬 法, 後者を Mayer 法と称した。

な特再手術例 49 例中 4 例は前手術によつて 鼓室前壁 が沿澺していたので除外した。

第3表に示したように耳管入口部の浩㽷しない症例 は，単純耳管摸爬の場合は Mayer 法を行つたるのつ 倍近くに達している.

鼓室全体が再び粘膜に被われて終ら症例は，単純䗉爬 群では 4例もあるのに, Mayer 法を行つたるのには1 例むない。

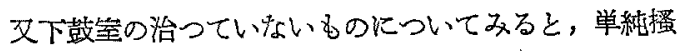
爬群は Mayer 法群の4倍以上に達している。これは

\section{第 3 表}

\begin{tabular}{|c|c|c|c|}
\hline & 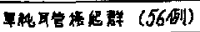 & Mayer 法群 (62例) \\
\hline & 造櫵例数 & 28 列 $(50 \%)$ & 47 例 $(75.8 \%)$ \\
\hline \multicolumn{2}{|c|}{ 不完全治看例 } & 28 例 & 15例 \\
\hline \multirow{6}{*}{ 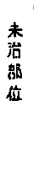 } & 酷空你方 & $6 \quad(566910.7 \%)$ & 9662 例中 $14.5 \%$ \\
\hline & 下融空。 & $8 \quad(143 \%)$ & $2(3.2 \%)$ \\
\hline & 耳管入口部 & $(16.1 \%)$ & $(6.5 \%)$ \\
\hline & 钱空全体 & $(7.1 \%)$ & 0 \\
\hline & 奏の他 & $(14.3 \%)$ & $(3.2 \%)$ \\
\hline & 2㐰防○强 & 7 & 2 \\
\hline
\end{tabular}

Mayer 法を行うと自ら下鼓室の㨟爬が徽底的になる事， 革び下鼓室が治らないのは，耳管粘膜が下鼓室に伸展す るためであろらと考劣らる。

これ反し，鼓室後方即ち両円器附近の治ら双症例は 両群の間に汪ら゙その差を認めない。

\section{(5) 遠隔成續}

i）手術時よりアンケートヌは再診迄の期間は第 4 表 の通りで，最短 6 月，最長 5 年 2 月であつた・

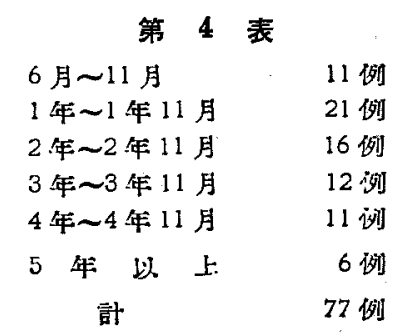

ii）治瘺成續の相違（第 5 表）

未治の䚈治療を中止した 27 例の中, 3 例洅検炕よつ て治瘾しているが，内 1 例はアンケートによつて乾燥し ている事が分るのみで，果して完全に表皮化しているか 否かは不明である.他の 2 例は直接再診して完全に表皮 化している事を確認した。この2例はいずれる術後 4 年 る経過していた。

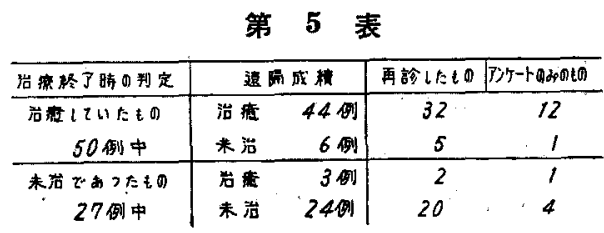

これに反し，一旦は沿癒したがその後再発したものが 50 例中 6 例ある.内1例は最近火なつて少量の粘液が 出る事を訴えるが再診していないので，病巣部位は不明 である.直接再診し得た 5 例の再発度巣部は第 6 表の通 りである (2 個所のるの 2 例). 


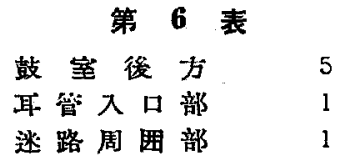

即ち全例とも鼓空後方に排膿病巣を有している。 豉室後方並びに迷路周囲部に再発昺巣を生じたのは， 後述するように手術時遺残された粘膜が一旦チステとな うて埋没し，表皮に被われていたものが，何らかの撛因 沙よつて活性化し表皮面化壊開放したものと考えられ る.

又耳管入口部の再発は，耳管が表皮を破つて開放した か，又は耳管周团蜂巣の再然が原因であるうと思われ b.

\section{5. 文城的考察及び考按}

1）中耳根治手術の治澺成績について

中耳根治手術の術後経過については古くから多数の報 告がある・しかしその手術適応，手術々式，後撩法及び 洽緊の判定が報告者によつて夫ょ異つているし，又記載 されていないるのもあるので,これ等を比較検討する事 は困難であるか゚，その内主なるのを列挙すると，

1) Grunert 31) 44) (1896) は 200 例の根治手術例につ

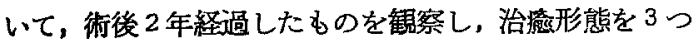
に分類している。

i）術創全面の表皮化したもの．ii）乳突部のみ表皮化 し，鼓室は正常粘膜の性質を有し，膜性洀痕による新生 㪗膜により遮断されているもの・iii）前者と同様なる る，新生鼓膜佀よる膜性遮断のないるの.

後年更に Reinking ${ }^{44)}$ (1907) はこれに 2 型を追加し た。

iv）壹室岬及び两円空附近に粘膜があり，耳管は開放 し他は表皮化しているもの，v）粘膜が殆ど術創全面を 被い，耳管の開放しているむの。

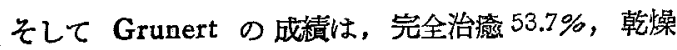
20.5\%となつている.

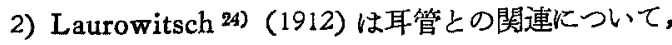
78 例を 5 群に分類した。

i）理想的治澢 - 持続的完全な表皮化，即ち表皮は光 沢を有し痂皮形成はなく，耳管は閉鎖している．26\%。

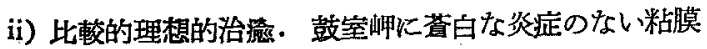
遗残があるか，又は施皮のあるるの，耳管は開放してい

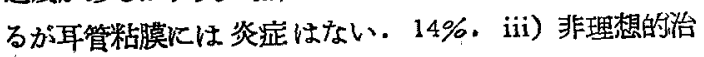

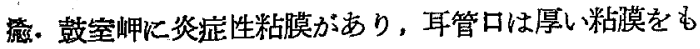
うて開口するか又は因茅があって泇皮を形成する。これ
を更に分必の断結的のもの（上気道又は外耳道からの感 染による) と，持続的のむのとに分ける. $33 \%$. iv) 鼓

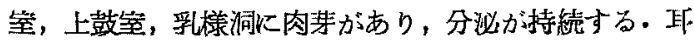
管口は表皮化しているが，耳管は表度下に粘膜管を形成 して上鼓室又は乳様洞に迄澾し，肉契又は瘦孔の部分で 開口している. $21 \%$ ，v)術創の種なな部位に肉势があ り分泌が持続する．分泌は耳管とは無関係で，肉芽の原 因として迷路壁のカリメス，スボルンの壊死，鼓室壁に 炎症性蜂单との他のあるもの．5.5\%．この内 $2.25 \%$ は 徐々に他の群に移行するので， $3.25 \%$ がこの群に属す る.

3）Lange ${ }^{31)}$ (1915）198例について，完全表皮化 42 $\%$ ，湿閏33\%，化髢性 25\%であった。

4) Henius, Schousboe ${ }^{14)}$ (1924) 135 例 150 耳rつ いて，完全治瘱 67 耳 ( $45 \%)$ ，不完全治瘾 83 耳であつ た。

5) Temkin 49) (1929）一次植皮を乳栐洞後壁，顔面 神経スポルン，上鼓室のみに行い，58 例中 $63 \%$ 沿湠 した.

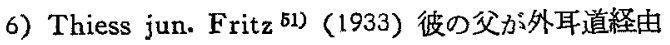
で根治手術を行つた 1500 例中 84 例を再唡した結果. 裴 皮化良好 70 例 (83.3\%)，少量の分泌 12 例 (14.3\%)，多 量の分泌 2 例 $(2.4 \%)$.

7) Kantz, Walter 18)（1937）術後 1〜10 年にわたる 26 例中, 完全治痛 14 例 (53\%)，少量の分必 8 例，多量 の持続的分速 4 例.

8) W. Mahn 28)（1938）10 年問の根治手術500 例に アンケートを求め，内 230 例を診察した。乾燥 $47.6 \%$ ， 湿閏 24.8\%，化膿性 $27.6 \%$.

9) Lieschke 25)（1950）140 例中一次植皮をした79例の 内 $62 \%$ が完全に表皮化したが，一次植皮をしない61例 では 23\%が完全に表皮化したに過ぎない。

10) O. Tepsen, E. Zweigius ${ }^{50)}$ (1951) 18 年間に根 治手術を行つた慢性中耳炎 156 例を手紙により再険した が，完全治療は74 例 (47\%) であつた。術式は鼓膜張 筋と両円空上の肉芽を取らず，耳管附近にも触れてい/ い.

11）仁保（三）36）(1953）100 例の慢性中耳炎（内14 例は根治手術後) 飞錐体手術を行つた。翰懆 $96 \%$ ，不乾 $2 \%$ ，庤太耳漏のあるるの $2 \%$ 。

12) Bánhidy, Fodor 2) (1956) 根治手術 180 例, 聴 保根治手術 170 例，乳様突起削開術 50 例計 400 例を 3 〜5 年後に観察した. 完全乾燥 $61 \%$ ，短又は長期間の分 
泌 $20 \%$ ，持続的分必之不完全裴皮化 $19 \%$.

Stacke 31) は根治手術の治癒を“生命に危険のある。 又は将来危険のある中耳化膿の馀去”とみなしている.

及 Grunert ${ }^{31)}$ 及び Mahn "8) は完全な裴皮化のみでな く，術創の一部が粘膜により被われる所謂“湿潤” の状 態をも治痖とみなしている。

元来根治手術の目的は合併症を予防すると共に，完全 に耳漏を止める事化ある事怙くから云われているとこ ろであるが，一旦根治手術を受けた患者には後日頭蓋内 今例症を起寸事悱常に稀であつたので (Lange 22) 23)， Neumann (4), Henius ${ }^{14)}$ ), 術創が完治 しない場合でも 手術の目的は達せられたと考えられた。

しかし近年は化学撚洁:の進歩之共に，合併症の予防之 云う意味は薄らぎ，耳鼎を完全に止める事が第一の目的

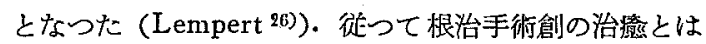
Mayer ${ }^{31}$ ) 等の云うように，完全な乾燥即ら術創全面の 完全な表皮化に限定すべきで，“湿涯” の状態をも治㗪 とみなす事はできないと荅えられる。

従つて，上述の治潦成績についての文献をみても，治

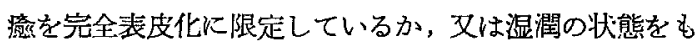
治簝とみなしているか判断に苦しむるのも少くないの で，表現の明らかなものを選:゙と完全な表皮化の\%は次 の如くになる。

$\begin{array}{lll}\text { Grunert } & (1896) & 53.7 \% \\ \text { Laurowitsch } & (1812) & 26 \% \\ \text { Lange } & (1915) & 42 \% \\ \text { Henius, Schousboe } & (1924) & 45 \% \\ \text { Thiess jun. Fritz } & (1907 \sim 1933) & 83.3 \% \\ \text { Kantz, Walter } & (1937) & 53 \% \\ \text { W, Mahu } & (1938) & 47.6 \% \\ \text { Lieschke } & (1950) & 62 \% \\ \text { 仁保三四次 } & (1953) & 96 \% \\ \text { 西 端 八 郎 } & (1958) & 62.3 \%\end{array}$

2）術創の難治部位について

根治手術の治撩を妨げる原因について，その最む大き な因子の一つと考えられているのは牥管である・耳管の 治痖に文济す影響については Siebenmann (1893) 以来 古くから注目され後述の如く多数の報告がある.

しかし根治手術創の治瘺し難い原因を知るには，術創 のいかなる部位が治り難いかを先ず検討する享かが必要で ある・しかるに根治手術後の術創のいかなる部位が表皮 化し難いかを，多数例について統計的に考察した文献は 殆ど見当らない。
僅かに Harpman 13) (1948) 方術後に分速のある病

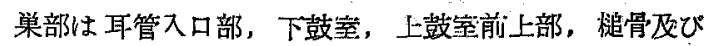
砧骨，半規管周囲稀に乳突尖端であると述べているが， 統計的な数值は示していない. 又当教室の川鴆，五十嵐 19）（1954）は根治手術後完全に治癒していない外来患者 112 例 118 耳の統計を挙げている。それによると，表皮 化しない部位は下鼓室及び耳管入口部が冉倒的に多く， 鼓室の何边から゙表皮化しないものは111 例, 94.1\%で， 鼓室が表皮化しているものは7 例 $5.9 \%$ に過ぎないと迭 ベている.

私の122 手術例の統計でも未治例 46 例飞ついて，術 創を乳突部(迷路周囲を含む) と鼓空周辺部とに分ける と，鼓室が治癒していて乳突部に病栄のあるすのは46 例中 3 例のみで，43 例は鼓室の何処かに病巣を有して いる。

又難治部位は 46 例 55 個所中, 孚突部は 8 個所 (14.6 $\%)$ であるが，鼓室周辺部は 47 個所 $(85.4 \%)$ で压倒的 に多い.

乳突部についてみると，迷路周囲が最も多く 46 例中 4 例 $(8.7 \%)$ 次で閣闒部が 3 例 $(6.5 \%)$ であつた。

鼓室周辺部では，耳管粘膜が伸展して鼓室を被うて終 つた症例か 46 例中 4 例 $(8.7 \%)$ あつた他，鼓音後方即 ち両円空附近が 17 例 (37.6\%) で最も多く，次で耳管 入口部か 13 例 $(28.2 \%)$ ，下鼓室 11 例 $(23.9 \%)$ ，上鼓 室 2例 $(4.3 \%)$ の順であつた。

即ち，一見して手術的操作を加える事の困難な部位化 多い事が明らかである。

Lange 22)（1910）は手術直後の 側頭骨標本を検索し， いかに完全に搔爬したつるりでる，鼓堂特に下鼓室に粘 膜の遺残が余りにも多いのは驚くべき程であると述べ， 顔面神経管，迷路空，蝸牛殼、形動脈芚び頚静脈球を有 する鼓焦壁から完全に粘膜を除去する事は不可能である としている。その他 Ruttin ${ }^{45)}$, Reinking(4), Wittmaack 55), Brunner 5) 6) 5も全く同様の事を述べている.

Lange 22) は更に，中耳枮膜将に耳管粘膜の異常に强 い再生能力に注目し，これが表皮化を㚲げる重要な因子 である季を强調し，遺残粘膜の不快な伸展を阻止するた ぬにはタンンポンによつて粘膜上皮の伸展を阻止すると共 に，扇平上皮へ化生せしめる事が必要であるとし，その 意味で無タンポン寮注に反㞶している。

Wittmaack 55)（1922）む文，このような遗残拈膜が 肉腿的に見える Schleimhautinselnに迄大きくなうて， 表皮化を妨げると述心，更に又肉莱組織は綮密な病理解 
部学的意味からは一般に重要な問題ではなく，粘膜と表 皮境界部で時に亳度の肉芽增殖があるが，臀密に検索し てみると殆ど常に Cystische Abschnierung によつて できた Epithelkanal が肉芽組織の基底に発見されると 述へ，少くとも遗残粘膜が分㴹の持続する重要な原因で あるとしている。

Brunner 5) 6)（1954）は根治手術創を重層扁平上皮に 被われるるの，立方乃至円柱上皮に被われるもの及び重 層扁平上皮と立方敃至円柱上皮との混在するものとに三 分し，その内でも第三の型唧ち粘膜の遗残がある場合が 予後最む要く，一の Epithelart が他の Epithelart を排除せんとして瓦に堌大した堌殖エネルギーがポり一 プ及び膿性分泌を薏起する事になるとる述べている。

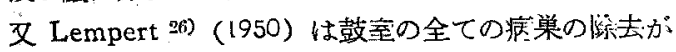
大切でその一部の残存む耳漏を永絸せしめるとし，肉 芽、ポロープ, 真珠腫のみならず, Mucoperiosteumを む除去して骨面を露出しなければならぬと述べている。

私の統計汇みられる如く，鼓室周辺が表皮化し難いの は，完全に粘膜を取除く事.のできない鼓宝壁の解剖学的 な困難さを先ず第一に挙げなければならない従つてこ の困難に逆つていかに完全に近く粘膜を除去するか，そ して宿命的に耳管更び鼓空に遺牫する粘膜片をいかにし てそれ以上伸展せしめる事なしに，表皮を早く張らせる かと云ら事が根治手術の成績を左右する最も重要な太子 であり，そこに中耳根治手術の困難さと術後处置の電要 さがあると考えられる・

こડで根治手術の治捡を妨げる原因として重要視され てきた錐体头について洘えてみたい、私の应例は全て迷 路周囲蜂栄を搔爬し，過半数において頸動脈周国を掻爬 しているが，所謂徹底䄪な錐体尖手術を行つたものはな いしかし私の不完全治澺例について, その術創の未治 部位をみると, 錐体失蜂巣が関与している可能性が考兄 られるすのは迷路周团 (1<2 例中 $3.3 \%)$ ，上鼓至 $(1.6$ \%) 及び管入口部 (10.6\%) の一部で放つて，百分率 からみてそれ程多いものではない，従つて慢性中耳炎に おいては後逊するよらに耳管周囲の閏題を除けば，所謂 側頭宜根治手術を行わなければならないるのは比较的少 数に過ぎないと考えられる・本して中耳根治手術を行つ て治らないものは錐体尖手術をすればよいと云う事は必 ずしも云い得ない。

3）耳管の問題について

根治手術創に耳管が閏放しているための 障碍につい

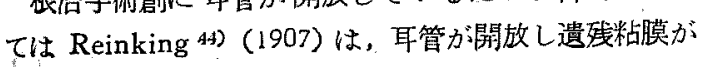

鼓室岬にあるのは非常に悪く，耳管から䏝がでるたぬに 粘膜が広く伸展し，不快な結果になると述へ，術後の粘 膜の伸展は粘膜の遗残か又双は管開放のためであると し，粘膜を完全に除く事は不可能故，耳管を閉鎖し粘膜 への炎症性，堌殖性刺㦸を避けるようにすべきであると 説いている。その方法として，耳管の周囲に上皮のない Zone を作り肉芽を上げて閉鎖する事を推奨し，この時 タンポンを强くすると肉芽発生を阻止し，この間に耳管 上皮と表皮とが伸展連絡して耳管が開放してしまうと警 告している.

Lange 92) (1910) は耳管粘膜は強い再生能力を有し ているので，肉帮形成の初其にすでにこれを上皮化して 終うと速へ，浼いて耳管を搔爬せず鼓膜を迷路壁に癒着 せしぬて膜性閉鉷を計つている・この際粘膜に炎症なく 膜性に閶鎖していれば害はないと述へ，再発は下鼓窒や 鼓䓊に残つた粘膜からで，耳管からではないとしてい ॐ.

これに站し, Laurowitsch 24) (1912) は根焅手術劍 の理想的治琲には耳管の完全な閉鎖が必要で，治揟しな い症例の大多数は耳管開放のためであり，耳.管の最終綃: 果についての態度は決定的であると述べ，耳管を閉鎖す るために骨片又は角等の㨀入汒を推奖している。

Wittmaack 55)（1922）6文同椂の事老述べ，耳管が

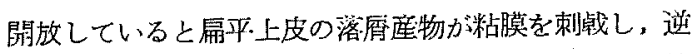
に絬膜の分泌が扁平上皮を刺㦸ずる。この夙上皮間の描 抗が治癒に悪い影響を及ぼすと述べている・彼は秉に根 治手術創の色々な形態について，次のように分類してい る・i）扁平上皮が鼓室内壁を被う以前に耳管からの粘 膜上皮が伸展し鼓空内壁を被うて終ら事が多く，この両 上皮は鼓堂と乳様洞との境の骨㦀起（鼓膜張筇及び顔神 管）で均衡を保つてこの状態が終生のものとなる，ii） ある例ではこの上皮下組織が誐痕化し，粘膜上皮の化生 によってこの境界部に移行上皮ができ，安定した状態に なる. iii）粘膜再生の驹、時は扁平上皮は鼓室内壁に達 するが，鼓至底や耳管口に遺残紿膜があるために治痛を 妨げる，iv）完全に表皮化しても耳管が開放している時

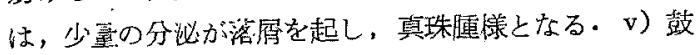
室内に舟平上皮に被われる組織の橋ができ，その下に含 気化の如く耳管から䊀膜が伸展して，粘膜《被われた腙: ができる事がある・vi）長い間には扁平上皮が増殖し遗 残粘膜王び粘膜管を消隇せしめて，完全な表皮化が得ら れる事がある。そして彼は耳管閉鎖の方法として，耳管

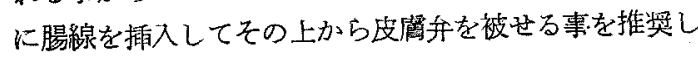


ている・

一方 Mann 27)（1912）は耳管入口部の治甞しないの

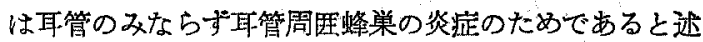

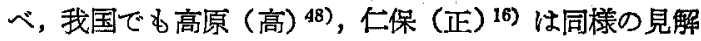
を有し，仁保，石川（1951）16）は耳管鼓室開口部につ小 て大なる役割を為しているのは耳管鼓室開口部附近ある いは耳管夫自身の中關口している錐体前蜂笨列の存在 であると述へている.

しかし反面, Brunner 5) 6) (1931) は根治手術後の9 側頭骨標本を検索し，耳管粘膜及び耳管周囲蜂巣に全く 炎症の認められなからた事から，再発の原因は外耳道か らの菌の侵入によつて，遺残円柱上皮に炎症を起すため で，再発の原因を経耳管感染火帰する傾向を否定し，又 耳管は再生能力が強いから提爬してる無䭾であるとして いる. Lange 229 (1910) あ亦下鼓室に炎症があるのに耳 管に全く異常を認めなからたと述べている。

耳管粘膜の術後の作展を阻止し, 所謂 Tubenrezidiv を防止するための耳管閉鎖については多くの報告があ るが，代表的のものを挙䏠ると，(1) 肉军による閉鎖 (Reinking)，(2) 完全搔爬 (Winkler)，(3) 鼓膜を漓 着せしめる (Heine, Lange), (4) 焼灼 (Ferreri, Habermann)，(5) 植皮 (Gerber)，(6) 骨片插入 (Laurowitsch, 北川)，(7) 晹線插入 (Wittmaack, Preysing, 森川)；(8) 䗗爬後植皮 (Oppenheimer, Wittmaack)， (9) パラフイン注入後植皮 (Gerber) 等であるか゚， い ずれも一長一短があり成績もまちまちのようである。

私は前述の如く, 耳管周囲の処置について, 主として 耳管粘膜を畄爬して植皮したものと，更に徹底して Mayer 法を行った後に植皮したものとに分けて比較し てみた.

即ち，Mayer 法を行つたもの」完全表皮化は $75.8 \%$ であるのに比し，単純耳管播爬群は $50 \%$ であつた，更 にこれを部位的にみると，耳管方面の 治らないものは Mayer 法群は6.5\%であるのに比し，単純搔爬群では 約 2.5 倍の $16.1 \%$ であつた. 又耳管のみならず下鼓絮の 治らない症例む Mayer 洁群は $3.2 \%$ であるのに比し， 単純掻爬群では 4.5 倍の $14.3 \%$ に達している。

術後鼓室全体不耳管粘膜が伸展して終う症例は単純提 爬群では4 例あるのに比し，Mayer 法群では1例もな かつた，唯鼓室後方の迷路空附近の治らねものは閣群の 闃に大差を認めなからた。

即ち，鼓室の治㵪成績に扣いては，Mayer 法は単純 耳管描爬法に比べて遥かに勝れた成績を示している。
この理由としては, Mayer 法によれば耳管周因蜂樂 と共汗管粘膜をより徹底的涂去できる事が考えられ る・従つて耳管入口部が治り難いのは耳管周目蜂童のみ ならず，耳管そのむのも重要な原因である事は明らかで ある・しかしそのいずれがより重要な因子であるかは私 の成績からは断定する事はできない。

4) 植皮について

私の症例は全て一次的植皮を行つているが，参考のた め昭和 25 27 年間に根治手術を行つた際，一次的植 皮を行わなかつた29 例を 任意に 選んでしらべてみた。

即ち，完全表皮化 9 例 $31 \%$ ，不完全表皮化 20 例 $69 \%$ で，一㳄植皮をしたものに比べてかなり成績が覀いのは Lieschke 25）の報告にも一致した傾向が双られる，即ら Lieschke は一次植皮をしたものは79 例中 $62 \%$ が完全 飞表皮化し，一次植皮をしなかつたものは61 例中 $23 \%$ しか完全に表皮化しなからたと述べている.

私の調べた不完全表皮化 20 例について，未沿部位をみ ると第 7 表の如くである・即ら，一次植皮をしない場合 は，鼓空全体に耳管粘膜が伸展して表皮化を妨げる症例 が全例中 $41.4 \%$ (12例) むあつた。 又 Mayer 法を行つた むのは 8 例であるが, この場合も成績が良く 8 例中6例 が完全に表皮化し，洽償しない２例は鼓室全体に耳管粘 膜が被らていた。单純耳管搔爬群は 21 例中 3 例 $(14.3 \%)$ 治渴し，治癒しない症例の $2 / 3$ は鼓室全体方耳管粘脱に 被われている。

以上の統計は少数例であるが性ら゙その傾向を筧う事が できる思う・即ち，一次植皮をしたるのとしなかつた あのとの比較から，遗残粘膜 (耳管粘膜を含めて) の術 後の伸展を阻止するには，可及的完全な粘膜の挰爬除去 と共酒一次的植皮が極めて有效な成績を示するのと考党 られる。

\section{第 7 表}

\begin{tabular}{|c|c|c|c|}
\hline 未宏部位 & 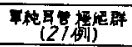 & 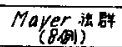 & 合㖕 \\
\hline 牙案全体 & 10 & 2 & 12 \\
\hline 耳苗入口郬 & I & 0 & 1 \\
\hline 耳十一下贆军 & 2 & 0 & 2 \\
\hline 进路㞵的近 & 4 & 0 & 4 \\
\hline 气标洞 & 1 & 0 & 7 \\
\hline & 18 & 2 & 20 \\
\hline
\end{tabular}

\section{III 第 2 章 術後性慢性中耳炎の臨床的並ひた 病理組織学的研究}

\section{1. 緒言}

根治手術を行つても治り難い部位は，鼓室を中心とし 
た部位である事は前暲に述べた・そしてそれは强爬不完 全による病的粘膜の遗残之耳管開放による耳管粘膜の伸 展によるものであろらと推定した。

そこでこれを榷認するために，手術を行つても治らな からた症例（これを術後性慢性中耳炎と称する）49 例 飞再手術を行い，病巣部を臨床的に観察し，更に々の中 から 15 例を選んで病巣部の病理組織学的検索を行つた。 そしてこのように病巣部を取除いてどのような沿痖過程 をとるるのかを観察した。

\section{2. 研究材料とその分析}

1) 第1章に扣ける 112 例 122 手術例の中から，中耳 根煰再手術を行つた術後珄慢性中耳炎 49 例を選んだ。

2) 性別 男 30 例, 女 19 例.

3) 年令

$5 \sim 10$ 才 1 例， $11 \sim 20$ 才 14 例， $21 \sim 30$ 才 26 例，31 $\sim 40$ 才 5 例， 41 才以上 3 例. 最年少者 9 才，最年長者 60 才。

4）前手術から再手術迄の経過期間

$\begin{array}{lr}6 \text { 力月以内 } & 1 \text { 例 } \\ 6 \text { カ月 1 年 } & 3 \text { 例 } \\ 1 \text { 年 } \sim 2 \text { 年 } & 8 \text { 例 } \\ 2 \text { 年 } \sim 5 \text { 年 } & 16 \text { 例 } \\ 5 \text { 年 } 10 \text { 年 } & 8 \text { 例 } \\ 10 \text { 年 } \sim 20 \text { 年 } & 9 \text { 例 } \\ 20 \text { 年 上 } & 4 \text { 例 }\end{array}$

5）前手術の術式

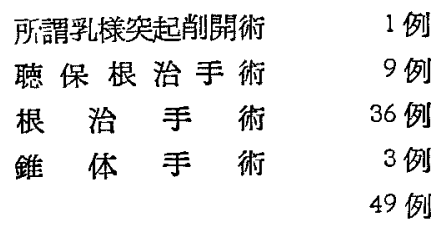

\section{3. 臨床的観察}

1) 前手術が所謂乳様突起削開術及び聴保根治

手術であつた群 (10例) について

この成績は第 8表の如くで，再手術によつて乳突部の 肉眼的に確認した病巣部は第9表の如くになる。

10 例中 2 例 (症例 6，7) は前手術時外耳道が整形して なからたので術前の乳突部所見は不明であつた・外取道 の整形してあつた 8 例中 3 例（症例 2，3，9）は取鏡应見 では乳突部が完全に治癒しているように見えた。しかし 奏際に治瘭していたのは1例（症例9）のみで，他はい ずれる表皮下に病的蜂巣があり, 鼓室の病巣部に連続し
第 8 表

\begin{tabular}{|c|c|c|c|c|c|c|}
\hline 庭例 & 住 & 45 & 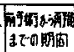 & 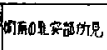 & 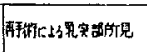 & 等果 \\
\hline 1 & 9 & 27 & 5 年 & 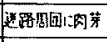 & 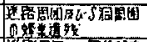 & 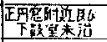 \\
\hline 2 & $\delta$ & 20 & 10 年 & 治推 & 1) & 完光 \\
\hline 3 & $\delta$ & 22 & 10年 & 治 索 & 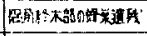 & 㝓治 \\
\hline 4 & P & 29 & $/$ 年 & 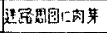 & 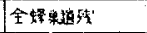 & 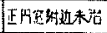 \\
\hline 5 & 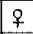 & 25 & 137 & 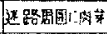 & 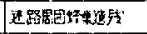 & 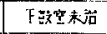 \\
\hline 6 & 오 & 36 & 4 年 & 不明 & 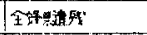 & 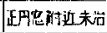 \\
\hline 7 & 9 & 32 & 3/年 & 不明 & 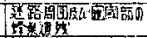 & 完 治 \\
\hline 8 & 우 & 22 & 9ケ月 & 因㩆部公的来 & 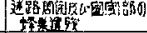 & 完 炲 \\
\hline$g$ & 우 & 22 & 15年 & 范留 & 治等 & 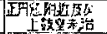 \\
\hline 10 & 早 & 9 & 6年 & 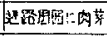 & 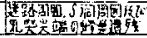 & 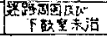 \\
\hline
\end{tabular}

第 9 表

\begin{tabular}{|c|c|c|}
\hline 症絭嘫位 & 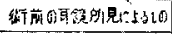 & 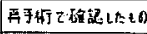 \\
\hline 究突部全体 & 0 & 2 列 \\
\hline 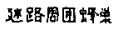 & 4 例 & 6 㑚 \\
\hline 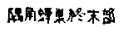 & 0 & 2 例 \\
\hline 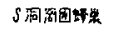 & 0 & 2 例 \\
\hline \multirow[t]{2}{*}{ 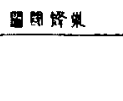 } & 1 别 & 2例 \\
\hline & 5列 & 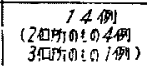 \\
\hline
\end{tabular}

ていた。

乳笑部の治瓷していた 1 例（症例9）を除き，他は全 べて乳突部に病的蜂盖を認め，これが病栄である事を確 認した・その病单の最も多い部位は迷路周囲であつた。

再手術の結果，迷路周井部が 表皮化 しなかつた 1 例 （症例 10）を除き，他の9例㤬て乳突部が完全に表皮 化して治癒した。

2）前手術が中耳根治手術及び錐体手術であつ た群 (39 例) について

この成績を第 10 表に緾めた。文再手術時に 確認した 病栄部の肉眼的所見とその部位第11 表の如くである.

この表の遗残粘膜とは，表面が平滑で粘膜特有の光沢 を有し，粘液分泌を認めるものとし，肉芽形成之は，表 面が顆粒状で周囲より隆起し，出血し易く膿性分泌の施 るものとした，勿論これは因腿的な分類であって組織学 的の分類ではない，従つて厳密に区別し得ない場合が多 W.

乳突部（迷路周团を含を，以下同様）の治療していな かつたむのについてみると，蜂槊の遺残があつたものが 大部分であり，肉眼的に肉薪形成のみでその肉芽の基底 に蜂盖のないものは迷路周四に 4 例（症例 $14,35,37$,

43）琵關部に1例（症例 45）のみであつた。

即ち，前項の 乳突削開術並飞 聴保根治手術群之同檬

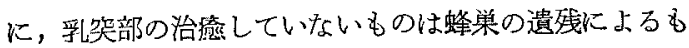
のが大多数を占めていることが分る。 
第 11 表

第 10 表

\begin{tabular}{|c|c|c|c|c|c|c|}
\hline 症例 & 精 & 年令 & 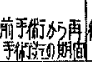 & 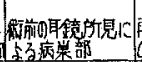 & 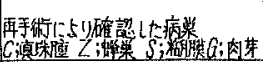 & 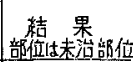 \\
\hline$M$ & $\$$ & 31 & 27 年 & 下彭空 & 下敋空 $G$ 㙂 $S$ & 耳管入ㄱ. \\
\hline 12 & $\Delta$ & 42 & 94 & 鼓室全体 & 䃌解Z 亄空全体 $S$ & 完 治 \\
\hline 13 & $\delta$ & 22 & 2月 & 唼空全体 & 䠌宝全体 J & 完 治 \\
\hline 14 & $f$ & 16 & 2年 & 鼓空金体 & 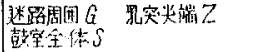 & 鼠闗很 \\
\hline 15 & $\hat{b}$ & 19 & 3年 & 吝空渚方 & 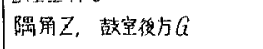 & 完 治 \\
\hline 16 & q & 22 & 2年 & 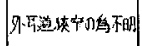 & 盛 $\mathrm{e}$ 鼓空後方 $a$ & 完 治 \\
\hline 17 & $\hat{\delta}$ & 26 & 7年 & 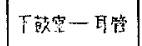 & 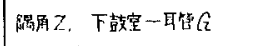 & 完 治 \\
\hline 18 & $\hat{0}$ & 23 & 4年 & 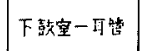 & 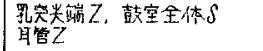 & 鼓空後方 \\
\hline 19 & 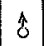 & 20 & 12年 & 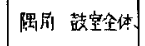 & 陆用Z，鼓宝全体 $\oint$ & 鼓空後方 \\
\hline 20 & $\hat{0}$ & 22 & 6年 & 款空全体 & 鼓空全体 S & 完 洁 \\
\hline 27 & $\hat{s}$ & 26 & 6年 & 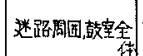 & 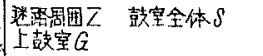 & 完 治 \\
\hline 22 & $q$ & 60 & $8 月$ & 耳 管 & 下跂室 $G$ 耳箮 $Q$. & 完 治 \\
\hline 23 & $\hat{s}$ & 24 & 2 年 & 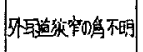 & 独突邵全体C & 完 治 \\
\hline 24 & s & 22 & 5 月 & 迷路周团 & 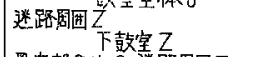 & 完 治 \\
\hline 25 & 8 & 28 & $2 /$ 年 & 耳管 & 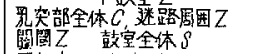 & 完 治 \\
\hline 26 & $\hat{0}$ & 44 & 3年 & 下站宣 & 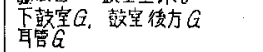 & 㪗宝後方 \\
\hline 27 & $q$ & 20 & 177 年 & 餃宣全体 & 鼓室全体 Q & 完 站 \\
\hline 28 & $\hat{b}$ & 18 & 3年 & 䛠宝後方，聅管 & 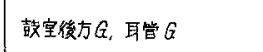 & 完 治 \\
\hline 29 & $\hat{\delta}$ & 32 & /年6月 & 鼓室全体 & 鼓空全体 $\delta$ & 完 站 \\
\hline 30 & $\hat{s}$ & 19 & 10 年 & 孚突加、鼓空 & 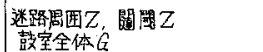 & 完 治 \\
\hline 37 & \& & 27 & 2年6月 & 鼓宝全体 & 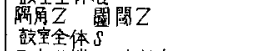 & 完 治 \\
\hline 32 & $\hat{\sigma}$ & 21 & 4年 & 鼓室全作 & 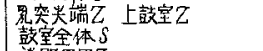 & 完 治 \\
\hline 33 & 우 & 20 & 16年 & $\begin{array}{l}\text { 送路淍团 } \\
\text { 鼓空全体 }\end{array}$ & 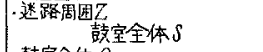 & 完 治 \\
\hline 34 & $q$ & 32 & 29 年 & 鼓空全体 & 跂宝全体 $G_{\text {耳管Z }}$ & 完 治 \\
\hline 35 & $q$ & 22 & 2年 & 遂路周团 & 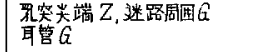 & 耳 管 \\
\hline 36 & $\hat{\jmath}$ & 17 & 3年 & F款室-故空後方 & 下㨬室－鼓室後方 G & 正丹空 \\
\hline 37 & $\hat{\delta}$ & 19 & 4年 & 蒾路周图 & 犹路恩困 $G$ 耳管 $G$ & 完 㫊 \\
\hline 38 & 1 & 27 & /年 & 鼓室全体 & 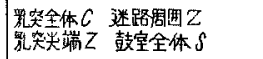 & 完岩 \\
\hline 39 & $q$ & 22 & 2年 & 下鼓宝，鼓宝後方 & 下竨室 $S$ 鼓宝後方 $S$ & 下鼓空 \\
\hline 40 & $q$ & 20 & /年 & 鼓宔全体 & 鼓室全体 $\mathcal{S}$ & 完 治 \\
\hline 41 & $\hat{\jmath}$ & 29 & 8年 & 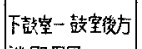 & 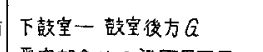 & 鼓宝後方 \\
\hline 42 & $\hat{o}$ & 22 & 17 年 & 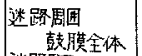 & $\begin{array}{l}\text { 乳突部全体 } C \text { ，迷路图困Z } \\
\text { 鼓空全体 } S\end{array}$ & 完 治 \\
\hline 43 & 우 & 22 & 4年 & 迷路䙵目 & 辝宝全体 $G$ & 完 治 \\
\hline 44 & $\hat{B}$ & 23 & 5 年 & 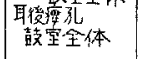 & 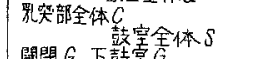 & 完 台 \\
\hline 45 & $\hat{o}$ & 20 & 4年 & 關闢，下鼓室 & 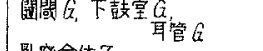 & 完 落 \\
\hline 46 & $\hat{b}$ & 19 & 8月 & 鼓室全体 & 楬突全体 $Z$ 鼓室全休 $\delta$ & 完 叁 \\
\hline 47 & $q$ & 27 & 2年. & 下鼓室 & 下鼓室 $S$ & 鼓宝㖟方 \\
\hline 48 & 우 & 23 & /年 & 上鼓空，鼓案後方 & 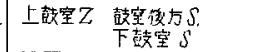 & 完 台 \\
\hline 49 & Â & 19 & 15 年 & 迷路置司 & 迷路周相 $Z$ 鼓空全体 $S$ & 完 治 \\
\hline
\end{tabular}

\begin{tabular}{|c|c|c|c|c|}
\hline & 逨珠模的 & 辣站残 & 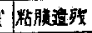 & 因来形的 \\
\hline 乳突酣全休 & 5 & I & & \\
\hline 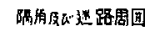 & & 13 & & 4 \\
\hline 間 首 & & 4 & & ' \\
\hline 西天光餪 & & 5 & & 8 \\
\hline 上攱堂 & & 2 & & 1 \\
\hline 致宝方 & & & 2 & 6 \\
\hline 下敖空 & & 2 & 3 & 6 \\
\hline 耳笛入口邵 & & 2 & 7 & 7 \\
\hline 酸垔全体 & & & 17 & 6 \\
\hline
\end{tabular}

一方鼓室の治瘾していないものでは, 鼓室全体が 粘膜に被われているもの以外は大部分が肉芽形成の みであつた。

病的粘膜を有する遗残峰栄及び鼓窒にみられた病 的粘膜は，それ自体病栄朽至排蜄源と見做し得る が，こっで問題となるのは，因眼的には肉莱形成の みであつて，その肉芽の下に病的肉芽を発生する原 因之考えられる䗋紧病的粘膜も認められない埸合 である・

そのよらな肉芽形成は乳突部に5 例, 敖安には大 部分の症例に認められた。

この肉来形成がいかにして長期間持続し，表皮化 を妨げ排訾するかという事については色ねの説があ り，その原因として遺残粘膜 (Wittmaack ${ }^{55)}$ 1922)， 骨病変 (Krebs 21) 21) 1912，仁保 ${ }^{16)}$ 1953，西端教授 3i) 38) 1956)，再感染及び後療法の不诵（Rambo 42) 1956, 堀口 15) 1957)，体質（Ohri 34) 1957）等が挙 げられている。

しかしこれを確認するには，肉芶組織の病理組織 学的㰸索が必要である・ところがこの肉茅組織につ いて詳沺に組織学:的検索を行つたのは Wittmaack 65) (1922) のみであつて，彼は前述の如く，肉芽組 織の基底に粘膜上皮を発見し，肉芽自体は決して重 要な問題ではなく，排澧源は遺残粘膜である事を強 調している。

私は 49 例の術後性慢性中耳炎の内，治癒しない 原因が手術の不徹底である事が明らかに分るものを 除き，前手術がかなり徹底して行われているのに治 瘺していない症例 15 を撰び，その病栄部の病理組 瀻学的㰸索を行つた.

\section{4. 病理組織学的研究}

1) 研究材料之方法

（1）再手術を行つた 49 例中，前手術が根治手術 
か又は錐体、手術であつだ群から15 例を選び本梌索の村 料とした。

（2）各症例の病栄軟部組織をその周囲の治㫌せる部分 と共に，一塊として慎重に骨壁から乹離切除し，濾紙上 に抬げ可及的速が $10 \%$ 小ルマリン液に投入固定後, 型の如くパラフインに包埋し 4〜6M 厚の連続甽片を作 㱔した。染色は P. Mayer へマトキシリン・エオジン 重染色を，文一部は Weigert 弾性線維染色を施した。

(3) 病巣部位の解剖学的関係から，病巣部の骨壁を検 荣に必要なだけの充分な大きさに削除する事は槯るて困 難であつたが，可能な限り骨片の採取に努めた。この骨 片は $10 \%$ 小ルマッン液で 固定後 5 \% 蕥酸夜で脱灰し， 中和後型の如くパラフインに包埋，4〜6M 厚の切片を 作襲し，H.E. 重染色を， 文一部の標本では八イデン八 イン氏アザン染色を施した・アザン染色標本は骬新生像 を検索する上灶甚だ有益であった。

その他一部の標本にグラム・ワイゲルト法により，組 織内細菌の検索を行つた・

2)研究成績

第 1 例：T. H. 18 才。

3 才頃から右耳漏あり，3 年前中耳根治手術を受け，3 月後一旦治癒した・しかし約9月て再び耳漏を生じ上後 持続している.

臨床所見：鼓室後方と耳管入口部附近飞肉苏増生が あり，少量の排膿を認める他性表皮化し乾燥している。

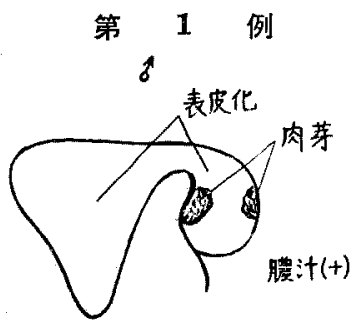

再手術：昭和 31 年 10 月 Mayer 法を施行した。術 後 38 日目に術創は完全に表皮化し，同 33 年 6 月現在完 治している。

病理組織学的所見:

(1) 鼓室後方

治痖部：表面は重層扁平上皮に被われ，上皮の最琵 㬝はェオジンに好染して著明に角化している．角質圓に

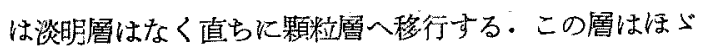
1〜2層の紡鍾形の 細胞からなり，細胞内にへマトキシ リンで紫色に染まる大小不同のゲトヒアリン顆粒を認
ふる・この下方の有栜尿は 3〜4 簤の多角形の 細胞から

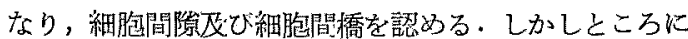

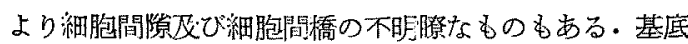
細胞は円柱形で豊富な黄褐色の色素顆粒を有している。

乳䪶の発育は良好ではないが，この上皮は外皮に和け る表皮の形態をほが整えている。

表皮下固有層は線維袖胞否び線維の增生が著るしく， 比較的血管比しい，又小円形細胞の浸潤むない，皮脂 腺，毛包を欠除する他，一般外皮に及られるような脂肪 組織を含む皮下組織はみられない。

病栄中心部：治療せる外皮に 取囲まれた病巣部には 病的粘膜がある。

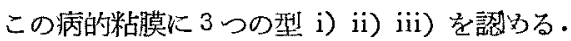

i）病的粘膜の表面は平坦で，これに隣接する治搰部 外皮表面とほ心゙同じ高さである（写真3），その移行部 は明膫で，治療部の表皮以粘膜部で突然消失しているか

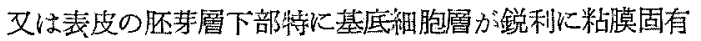
層内に少しく進入している。

この粘漠の上皮は大部分脱落して呫り，一部に残存せ るものは 2 列円柱上皮で，上皮細胞は多くは変性してい る・上皮值下には多核白血球の遊出を認め，上皮下固有 層の浅い部分では小円形細胞の浸潤中等度で，血管新生 も中等祭に認められるが，結合組織は比較的蹯でする。 浸潤高度のところでは淋巴球か結笛様に集積していると ころがある。

固有㬝梁部には細胞浸潤はなく，結合組織は密で線維 増生が著しい。

ii）病的粘膜の表面は孚跴状に笑出していて，表皮に 被われた治瘉部に接するところでは病的粘膜が楔けた凹 宿し，この部で治癒部の表皮は消失している(写真 4). 粘膜上皮は大部分脱落しているが，烰嘴状汇突出した 部の表面にはところどころ1間の円柱上皮細胞が残存し ている. 粘膜固有層には因芽の形成が盛で小円形緗胞の 浸潤は極めて强く，毛細血管の新生も極めて盛である。 又ところどころに多核白血球の遊走を譛める.この固有

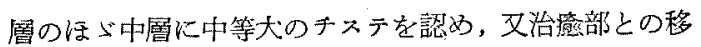

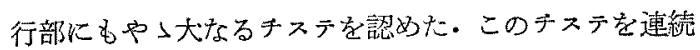
切片でみると，上記治癒部に移行するところの凹陥部の 粘膜が固有層梁部仙進入して形成されたものである事が 分る.こ机等チステの内腙注被ら上皮は大部分脱洛して いるが，一部に变性著るしい1圈の高円柱上皮細胞が残 存している.固有㬝潹部には小円形細胞の浸潤なく，䋨 合組織は密でところにより般痕化している。 
iii）病的粘膜の表面は凹凹不平で，2 3 個の乳知状 に突出せる突起部と，突起部の間が湾入乙てできた湾入 部とがある・この湾入部は時に狭湓となり梁く固有層内 へ進入して山宿を形成している (写真 5). この病的粘膜 は前二者に比べて遥かに広沉である・治噞部との移行部 では表皮は劃然と消失している・粘膜上皮は大部分脱落 しているが一部に重層円柱上皮が残存している・文湾入 部の盲端附近にす重層円柱上皮が認められる。この湾入 部の表面に近い部分は狭窄し，チステを形成する傾向を 示している. 粘膜固有層は一般に小円形細胞の浸潤極め て強く，乳嘴状突出部では特に毛細血管の新生が著るし い. 即ち，炎症性肉芽の形成が顕著である。多核白血球 の遊走は殆どなく，出血も軽度である．固有層の樑部に は細胞浸潤はなく，結合組織は㑻でところにより政痕化 している.

病紧周辺部：上記病的粘膜に隣接する表皮に被われ た部では常に多少とも炎症が波交している。即ち，表皮 下固有㬝には小円形細胞が軽〜中等度に浸潤し，表皮は 治潦部に比し 2 3 倍に高さを堌している．固有層深部 には小円形沺胞の浸潤はないが，ところにより出血を認 め結合組織の蹯なところがある・このような変化の見ら れる表皮下固有層にチステを認める事がある・チステの 内壁は扁平細胞飞被われ，内腔江䋓鉦形の上皮性細胞を 認めた・チステの外周は密な結合組織によつて囲繞せら 礼線維の增生が強い，しかしチステ附近の固有層ではむ 乙ろ結合組織は蹯である。

第 2 例 K. O. 35 才 $\delta$

小児期より右の 持続的耳漏あり，昭和 30 年 5 月根治 手術を受けたが治䋚せず。

臨床所見：乳突部は乾爆表皮化しているが，鼓室に 膜性輪状愥窄を生じ下鼓室，耳管から少量の排脿があ る・その深部の鼓室壁は表皮化しているように見える。

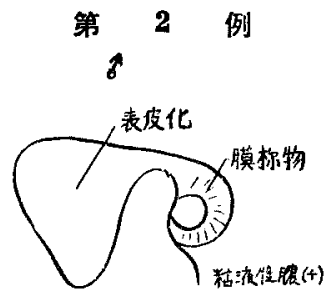

再手術：昭和 31 年 11 月 Mayer 洗を施行, 術後 29 日目に完全に表皮化し，33 年 7 月現在完治している。 病理組織学的所見：

\section{（1）鼓堂の耳管入口部附近}

治痖部：前淀例の治渏部所見と同樣であるか゚，乳頭 の発育は極めて良好である。

病栄中心部：こ」は粘膜で，上皮細胞は大部分脱落 しているか゚，一部湾性著るしい多列乃至重層円柱上皮 が残存している.表面には数カ所深い凹陷を形成し， 固有層队へ迂曲しながら複雑に入り込んでいる．この四 陥の一つにチステを形成する傾向のすのがある.

病巣粘膜の 固有層は一般飞小円形細胞の 浸潍著るし く，ところぞころ少量であるが分葉多核白血球の遊走を 認めた。

病栄周辺部：治㵪部表皮が病巣粘膜部に近すくく従 つて表皮はその厚さを増し，角質層もこっでは治癒部に 比しや小肥厚している. 又1〜2の乳頭はその高さを増 している・表皮下固有層の浅簤には中等度の小円形細胞 浸潤を認めるが，哚㬝には浸閏はなく線維増生著るしく 洀痕様となつている。

病巣粘膜部に近いところでは，殆ど著变のない表皮が 固有層から遊離している像が認められる．この表皮は基 底細胞屬と共に離脱しているが，病的なものか人工的の ものかは不明である・しかしこの部の固有層は肥厚し， 小円形細胞浸潤及び毛泪管新生共に高度で肉芽形成の像 を呈している・この梁層は撚痕様であるが治療部に比し 小血管が多く認められた・こつではチステを諮めない。

（2）正円空窝附近の肉芽様組織一䚶載省略

（3）耳管入口部附近の骨壁（写真 16）

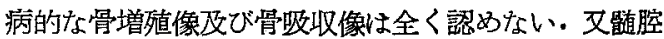
内にも小円形細胞浸潤及び線維細胞の増殖を認めない。

第3 例 T. O. 27 才 $。$

16 才の時から右耳漏あり，炤和 28 年，同 30 年と 2 回 根治手術を受けたが 2 年後に再発す。

臨床的所見：乳笑部は表皮化しているが 術創腔は浅 い. 鼓室には輪状狭窄があり粘液性膿の排出をみる。

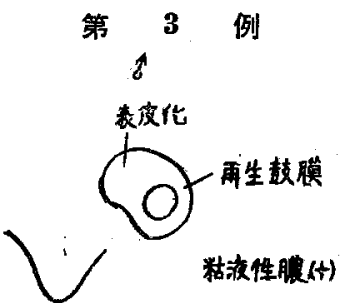

再手術：昭和 31 年 12 月 Mayer 法を施行，術後 20 日目に完全に表皮化した。

病理組織学的所見： 


\section{（1）下 鼓 至}

病巣中心部：粘膜部の記載省略·

粘膜固有層に接着している骨注細長い骨片であるが， これは恐らく䗋栄の骨梁の一部であるう・この骨には特 飞病的所見を認めない，又小打形細胞の浸潤高度な部分 飞接する骨飞も特行著师な病的変化を認めない，しかし 結合組織細胞の堌殖著るしいところでは著朋な骨增殖像

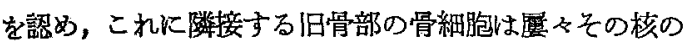
澧縮せるるのを認める。

第 4 例 T. N. 21 才。

奻児より左耳漏あり，昭和 28 年に根治手術を受け一 且治癒したがその後半年で再発した。

臨床的所見：乳突部は表皮化し 乾燥している，聝室 には因莱㥞組織があり排膿多量である。
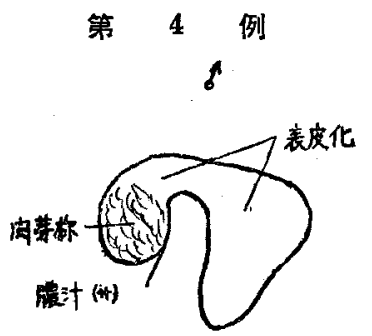

再手術：昭和 32 年 1 月 Mayer 浩を施行。術後 24 日目に完全脿皮化し，同 33 年 7 月現在完台している. 病理組織学的所見:

（1）治噪していた乳突部の外皮 表面は重篔扁平上皮に被われ，表䁲は著朋に角化し， ところにより極く薄い淡明層を有するところがある・こ の上皮細胞恃各層共一般に変性の傾向がある。即ち，細 跑恃空胞化し，核は濃綠してへマトキシリンに濃染し， その形は不正形で 細胞の一側に 偏在しているものがあ る・顆粒㒶にはケラトヒアリン顆粒を，文有棘層には細 胞間隌及び細胞間橋を明瞪に認める・乳頭の形成はこの 切片のどこにも認められない，表皮は一般に固有㬝の小 円形細狍の浸潤があるところでは厚く，浸潤のない部位 の表皮の 2 3 倍に達する．乙加し固有層に出血があつ てもその部の表皮は厚さを增していない。

表皮下固有層に 1 個のチステを有するところがある。 このチステの周辺は小円形細胞の浸潤が高度で，結合組 糡細胞及び線維の増生著るしく文毛細血管の新生が盛で ある.ナステの内腔挝数個の扁平〜紡釿形の上皮細包 か認められる.これ等の細胞はチステの内膑を横ぎり且 つ交叉しながら夫ふ内壁に達する 2〜3条の紐状の粘液
様物質の内に，ほ心1 列に包埋され，一見籠細胞の如く に見充る。この粘液様物質は土ォジンで淡染し，アザン 染色では青染する・チステの外方では，表皮淔下の結命

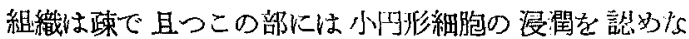
W.

（2）鼓室

記載省略.

第 5 例 F.S. 20 才 \%

4 才の時右側中耳炎に䍜患し，同年に 2 回手術を受け たが排膘が止をない。

臨床所見：耳後部に㾝孔を形成し，乳笑部は活ら゙裴 皮化し幹燥しているが隅角部は浮腫状で一部肉芽様にな

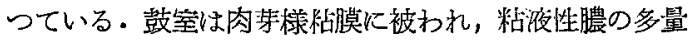
排出がある。
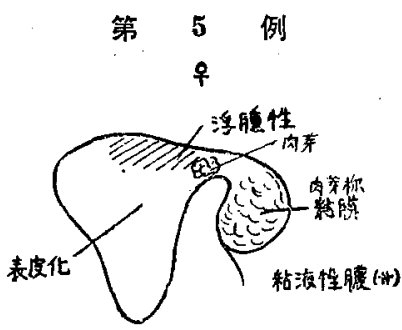

再手術：吱和 32 年 1 月 Mayer 法を施行. 10 力月 後に完全に表皮化した。同33 年7月現在完治している。 病理組織学的所見:

(1) 迷路周团 治䠖部：記載省略

病童中心部：こ১は病的粘膜であつて，その上皮細 胞恃大部分脱落し，僅か火残存するすのは变性著るし く，その形態は明らかではない，固有層は小円形細可包の 浸潤が極めて高度で，洏管の新生又著るしく旺盛で，か

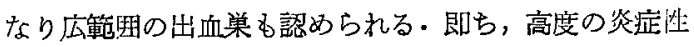
肉芽の形成認石。

病巣周辺部：病栄沾膜に隣接する部位の表面は重圈 扁平上皮に被われるが，角化は著朋でない，文顆粒凅に 相当する部はナラトヒアリン顆糊が不鮮明である・しか

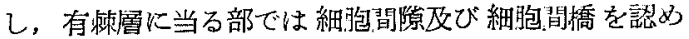
る.病巣粘膜に近い部の上皮中には多数の多核白血球の 遊走しているところがある(罕真 22)，乳頭の形成は軽 度である・上皮下固有㬝は肥厚し，結合組織は比較的柾 で小り形細胞の浸閏は中等度である。

\section{（2）鼓室}

病举部：病的粘膜であつて，上皮は大部分脱落して 
いるが，一部に变性著るしい排列不整な重周円柱上皮が 残存している・ところにより表面に突出した肉芽性の乳 眦计突起を認好る。

又この標本に 1 個の鼓室腺を見出したが，その開口部 附近の上皮は2〜多列円柱上皮で，その間にところどこ ろ繊毛を有する円柱細胞が散在している。一般に上皮下

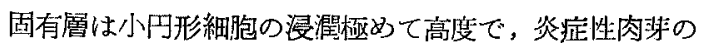
形成が著明である・鼓至腺の紸断面をみると，開口部か ら樑部一向う導管は単層瀻毛円柱上皮に被われている。 織毛は尊管が梁部へ進むに従い次第に脱落して行く，こ の導管の近くに1個の阽液性腺管（写真 20）を認めた。 この標本を連続划片で更に追瓜して行くと，この腺管は 管壮瑔で梁部でテステようとなり，腺上度細胞が内胵沉 脱落しているところがある・又この脱落上皮細胞が互に 融合して巨細胞を形成する移行像か諗好られる。

鼓堂腺の附近に大小不同のチステが 2 , 3 誌められる これらのチステは粘膜の山宿によるものであろらと思わ れる・即ら，このチステの壁には肥厚せる基底膜が認め られる(写真 19) が，腺テステには上皮下にみられるよ らな硝子様の基底膜を認め難いからである・チステの内 壁は1〜2層の立万上皮に被われて敌り，複雑な湾入を 示しているものがある. 又巨細胞を包含したチステは一 部の壁が破れて，チステの内容が巨細抱と共に附近の維 合組織間に漏出している像が認められる。

第6例 F.S. 32 才 9

3才の时に耳漏を生じ同年根冶手術を受けたが，耳漏 は停止しない。

臨床所見：乳实部は表皮化し 乾燥している・誥室は

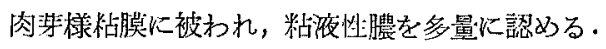

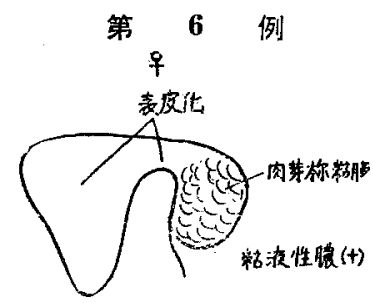

再手術：四和 32 和 3 月 Mayer 法を施行. 術後6 力 月で完全に表皮化した。畹和 33 年 5 月現在完凅してい る.

病理組瀻学的所見:

（1）鼓室耳管人口部（写真9，10）

治寂部：記裁省略
病栄中心部：粘膜であつて，その上皮細胞は大部分 脱溚しているが，病巣周辺部の表造に近いところた変性 した軍層円柱上皮が散在性に残存している・上皮下固有 喼は小円形細狍浸:壁が中等度で，血管の新生む中等度に 旺盛であるが，多核白。血球の遊出を認好ない。

病巣周辺部：上記病巣粘膜の甪側ふ表皮に被われて

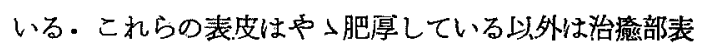
皮と異るところはない，表皮下固有㬝は表皮直下で一部 結:合組織の棘なところがある他は，一般て結台組譈滵で

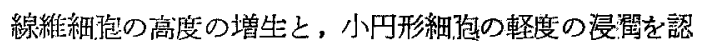
めるが，白血球の遊出を認奴い，血管の新生注軽度で ある・

固有㬝の浅層に粘膜凹陌がほよ゙長三角形の断面として 現れ，その内面は变性した多列円柱上皮に被われて格 り，一部には上皮の脱落しているところがある.

又固有層の中層から梁䁲にかけて，互に接する5 個の チステが認められる・チステの内壁はいずれも単層の立 方〜円柱形上皮細胞，一部は扁平細胞绕被われている。 これらの上皮細胞は多くは筀胞化するか，あるいは大小

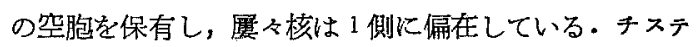
队腟炕は上皮性巨細胞五び脱洛上皮細胞を認め，一部の 巨細胞柇多核白血球を食喰している・これらのチステの あるむのは互に交通し，一方より他方にその内腚をエ木 ジンに焁染した滲出液樣物質が流動している・

(3) 鼓堂後方 (写真 9)

治療部：記載省略

病栄中心部：こ」は粘膜で、梁い凹陥を形成し，そ の表面は上皮細狍を殆と認わず，病栄周辺部との移行部 に僅か站方上皮緗胞の 2 3 個を認めるのみである。 固有層は小円形細胞の浸潤及び血管の新生を中等度に認 わる. 又出血を軽度に認奶るが，白血球の遊出はない。 固有層の深層には極く軽度の小形細胞の浸閏を認为 る.

病栄周辺部：病栄粘膜を狭み气の両側に 重層扇平上 皮に被われた部分がある。

その外耳道側に当る上皮はや〉厚さを增し角化が著玥 でない他は，沿漠部の表皮と異る所はないこの固有層 はかなり厚く，上皮直下の結合組織は眯で，中㬝には小 円形細包の侵潤及び血管の新生を中等度に譛奶るが，深 層では極く軽度である。

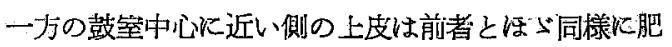
愿しているが，その構造は完全な表皮の形態を整えてい ない. 即ち，表層に角化なく1〜2層の扁平細垉他被わ 
れ，その下部に 3 4 層の円柱細胞が 重層组に排列して いる.この円柱細胞層には細胞閒隙と細胞間橋を認める がケラトヒアリン顆粒や色素顆粒は認められない。この ような奇異な所見は不完全表皮化と考えられる。この上 皮は病宩中心部に近すくに徉い表尿から漸次消失し翡薄 となり，移行部では重㬝円柱上皮となつている。な机乳 頭の形成は認めない上皮咱下は結合組織眯て小円形細 胞の浸潤は極く軽度である. 固有層の梁漫は一般に線維 增生が著るしいここ上皮下固有層に卵门形〜们形の中 等大のチステを認める・これ等は病巣粘膜の山宿から斜

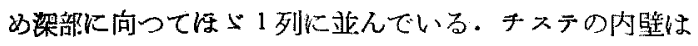
1〜2層の立方～扇平上皮細包に上つて被われ，その内 腚注はォジンに淡く染る渗出液梾物質が刷毛で掃いた よらに認められる.この内に上皮性巨細胞及び脱洛上皮

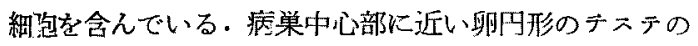
周辺には小川形細胞浸閏辰び血管が 中等量に認められ る.

(3) 鼓安中心部

重甾扁平上皮に被われた部分と多列円柱上皮に被われ た部分が随所に混在している，重層扁平上皮は発育悪く 未完成表皮である.この未完成表皮と円柱上皮との移行 部は明暸でなく，表層から漸次消失して基底細胞層がそ の睢移行しているよ5に見える。円柱上本に被わ机九部

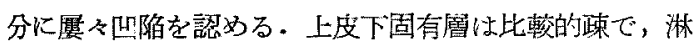

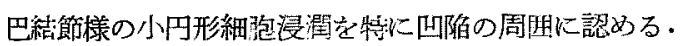
又粘膜凹陌がチステ様の横断面として現われる他，閉鎖 性チステる屡々認わられる。

凹陷の形は色々で入口部が広く内面に凹凸を示しつ〉 狭くなつて行くもの, 入口の狭い壹状のもの, 長く屈曲 した瘦孔を有する不骐則な形をしたチステ様のもの等で ある・四陷の上皮は多列的柱上皮又は1〜2層立方上皮 で，多くは内容が空虚に見えるが，一部に粘夜様物質に 包理された大単核細胞，脱楁上皮細胞及び淋巴球等を認 める.

第7例 Y. O. 17 才。

2 才の時から左耳漏があり，炤和 29 年根治手術索受 けたが完咨しない。

臨床所見：スポルン附近に小さな肉芽があり，鼓室

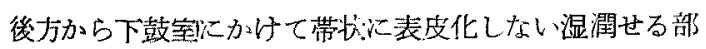
位があって排膿を認める。その他の部分は表皮化してい る.

再手術：昭和 32 年 7 月病巣部を中心としてその周辺 から剝離㻌去した後植皮したが，同 33 年 8 月現在な拉

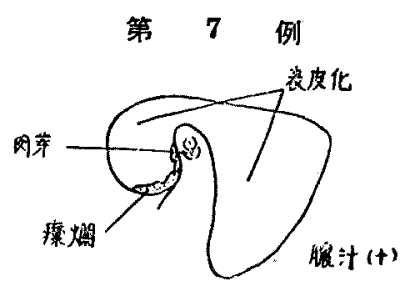

正订空窼附近に乾燥せ欢部分がある。

病理組織学的所見:

(1) 鼓掌後力

治痖部：記載省略

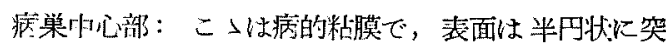
仙して粘膜上皮は覀く脱落しところどころに基底細胞が 残存している. 固有層は小円形細胞の浸濯極好て高度 で，毛細血管の新生も著るしく旺盛である、特に表圂近 くには新生毛細血管が密集して恰も血管胴を見るようで ある、又出血も著明である・即号高度に肉芽化してい る。

固有層の梁部には 1 個のチステを認める・内壁は軍層 上皮であるが変性著るしくその構造は不明膫である.内 容は容虚に見えて，巨細胞も上皮性細胞当認められな い.

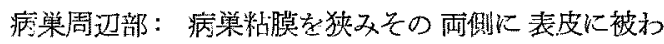
れた部分がある。

一側ではその境界はかなり明膫で，表皮は病巣粘膜に 近いところではや」菲薄となり，角化著明であるが，有 就層の細胞は变性し空胞化している・表皮下゙固有層の所 見は病栄中心部と活ざ同梯であり明らかな境界はない が，治瘉部との境界は劃然としてこつに皮脂腺を有して いる. 皮脂腺の存在は前手術後の植皮によるものであ る.

反站側の表皮は，病巣粘膜に接するところで著るしく 肥厚し治癒部の潘ぶ 2 倍に達している. 固有管も肥厚し ているが，病巣部を離れるに彷い潮次厚さを減し，小今 形細胞の浸潤も次第に被少している。

（2）下鼓音

治療部：記载省格

病栄部：この標本では病樂拈膜が、表皮に被われた治

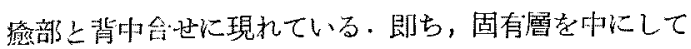
一方淁皮が，他方に粘膜上皮が見られる。これは表皮 下 Hohlraum の壁の一部であって，粘裳上皮は Hohlraum の内面を被らていたのである。

粘膜の表面は乳㗪状汇突出し，その上皮細胞は大部分 
脱落している.乳跴状突出部のほつ中央に 2 買の変性し た円柱上皮に被われた凹陌がある。その澡部の上皮細胞 には空胞化したものが多い，上皮㨁下の結合組織は踈 で，上皮下の基底膜は不明瞕である・上皮の脱落した乳 嘴状突出部は小円形細胞の浸濯高度で，血管も豊富とな

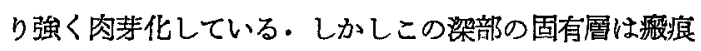
化している。この粮痕組織を境として反站側の表皮下固 有層に移行し，更に表皮に達する。

この表皮に被われた側の固有層は深部で艘痕化し，浅 層では結合組艛眯となり小円形細胞の浸潤なく，少量の 血管を諗める.又こにも植皮に基ずく皮脂腺が多数散 在している.

(3) 下鼓空の骨 (写真 7)

骨梁の間を埋める結合組織は一般に眯であるが，小円 形細胞の浸湭著るしいところでは極めて泌で踪維細胞及 ひ線維来細胞が著るしく増生している・こには殆ど血 管を認めないこの泌な結合組織に接する骨梁には緊々 エホジンに淡染する板けの類骨組織を認める・類骨組織 はアザン染色で淡青色に染まる.又䯘梁の表面には䚄な 造骨細胞を認め，ところによつては㭃若な骨細胞を含む 骨新生像が認められる：これらの新生骨はアザン染色で 青染する・一部にUmbau を認めるが，病的骨吸收像 欢び骨爙死像は認めない，この骨増殖は既存の骨より増 殖したるのである。

第8例 Y.A. 20 才 $\delta$

11 䪱から右耳漏があり，昭和 28 年10月根治手術 を受けたが治触しない。

臨床所見：迷路周团部及び 耳管入口部附近に 肉芽を 認めるがその他は表皮化している・耳管入口部より少量 の排膿がある。

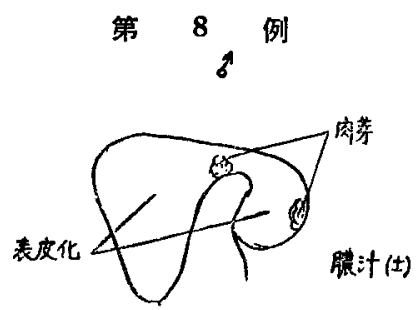

再手術：昭和 32 尔 8 月 Mayer 法を施行. 術後 2 月で 完全に裴皮化し，同33 年 10 月現在完治している.

病理組織登的所㫕:

(1) 迷路周国部 (写真 15)

病巢中心部：かなり広沉な粘膜で高度に肉沣化して

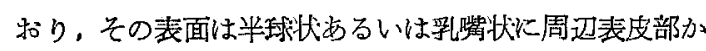

ら笑出している. 又ところによつてはこれらの因芽化し た笑起が脱落している・乳嘴状突起の間にてきた湾入部 には変性した多列〜重層円柱上皮が僅かに残存している が，その他の部分では上皮は悉く脱落している。上皮下 基底膜は著明に認められるところと不朋なところとがあ る・湾入部では均一等賀性の薄い膜様の粘液様物筫が表 面を被い，この膜様物の中に 脱落上皮細胞及び 2〜3核 を有する数個の巨細胞が包含されている。

固有層には小円形細胞の浸潤が極めて高度で，ところ により淋巴綜節様に淋巴球の集積したところがある。毛 細血管の新生が著しるく旺盛で，特に表層では密に集合 しその附近に線維素様物質の析出を認める. 又こっでは 多核白血球の遊出と出血が著るしい.

固有層梁部にナステを認める，その上皮は大部分脱落 し，残存せる上皮は 2 列円柱上皮で内腔に粘液榚物質と これに包まれた脱落上皮細胞を認める・文他の小さなテ ステ内に上皮性巨細胞を認めた。

病笨周辺部：表面は汪心完成した表皮に被われるが， 病栄粘膜に接するところでは角化著朋で表皮は肥厚して いる・乳頭の形成はない、基底細胞の色素顆粒は病巣粘 膜に近ずくに征い消失している.

固有層は一般に病盖粘膜の近くではや〉肥厚し，結合

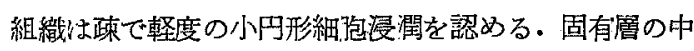
層では細胞浸澼は中等度で血管が答数認められる・最潹 層では細胞浸浧は整度である，又病巣粘脱より遠く離れ た部位に迄軽度の細胞浸涯を認めるが；表皮には異常を 認めない，最も離れた部分に皮脂腺を認めたがこれも植 皮によるむのである(写真 23).

(2) 耳管入口部

治挾部：記載省略

病巣部：肉芽様に 見えたるのはこれを镜検すれば病 的粘膜であつて，その上皮は多列円柱上皮で一部は変性 が著るしい，上皮の脱落したところでは上皮直下に当る 部分にや」肥厚した基底膜を認める. 固有層には小円形 細胞の浸潤が極めて強く，血管も中等度に新生し肉芽形 成が著明である。

第 9 例 E. N. 22 才

生後 I 年頃から右耳䨕あり，昭和 30 年 6 月根治手術 を受けたが時々少量の耳漏がある・

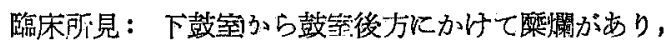
少量の粘液性分泌物を認める他は表皮化している。

再手術：昭和 33 年9月病巣部を周国組織と共に虽離 除去後植皮したが，現在な扣正円空简附近に小さな糜燘 


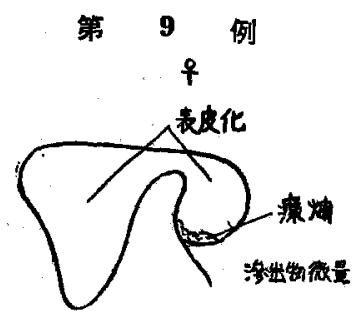

がある・

病理組織学的所見

(1) 下 鼓 室 (写喜6)

治揄部：記載省略

病巣中心部：こふは粘膜であつて周辺の 沿蒸部から 兵状火膨隆している・上皮は大部分脱落して一部に残存 せるものは变性萎綰せる多列円柱上皮である・粘膜の表 面㥛く菲薄な膜状の線維素様物質に被われている。

固有層は残存上皮の下ではや〉その厚さを娍し，上皮 直下に基底膜を認め，上皮下は線維細胞の増殖著るしく 又小円形細胞の浸潤は中等度である・粘膜上皮を欠如し た部分では上皮直下に相当する部分に基底膜を明瞭に認 め得ない。この部の固有層は著るしく肉茅化し，浅層に

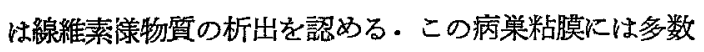

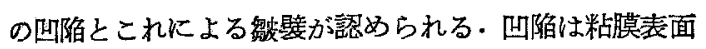
から深層に向つて狭細な管状あるいは裂溝をなして進入 し，璉々の方向に複雑な側枝を出している・中には固有 層の最深部に迄達するものもある. 又ある切片では，こ れらの側枝が大小種々のキステ様の横断面として現れて いる・これ等凹猴の浅、部分は2 層の円柱上皮あるいは 重層円柱上皮に被方九，深い部分は単層立方〜単尿円柱 上皮に被われている。時には扁平上皮に被われ内腔に上 皮性巨細胞を含むるのあある・これ等の上皮は一般に大 部分変珄脱落しているが，残存上皮の直下には多く基底 膜を認める。

その他，これ等の凹陷附近あるいは出陥と凹陷犯狭 れたところに閉鎖性肉芽腫を認めた（写真 14). 即ち， 肉芽腫の中心部は变性壊死に宿り，その周辺部は血管豊 富で線維芽細胞及び線維細胞の增生著るしく，更にその

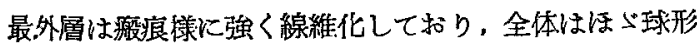
を呈しているこれを連続切片で追求してみたが，表面 に破壊していない。

病巣周辺部：病巣粘膜に接する表皮はかなり肥厚し ているが、これを遠さかるに徒つて菲薄となり治療部に 移行する・粘膜との境界は明膫である. 表皮の構造は肥 厚している以外は特に異つた所見はない。
固有層も又肥厚し治湑部に向うに徒い菲薄となる・こ の表皮下に 2 層の円柱上皮に被われた粘膜出陌があり， 表皮面に度孔を形成している.その横断面は円形チステ 様である. 又肥厚した固有層内にも病栄中心部之同様の 閏鎖性肉泺腫を2〜3 個認めた。

第10例 Y.I. 21 才

小巟期より右耳漏を認め, 昭和 25,29 年の 2 回根治 手術を受けたが少量の耳漏が持続している.

臨床所見：全術創は一見表皮化しているように見元 るが，鼓㗌は何となく湿潤している。

再手術： 昭和 32 年 8 月 Mayer 法仁上り施行. 術後 20 日で完全に表皮化した. 昭和 33 年 6 月現在完治して いる.

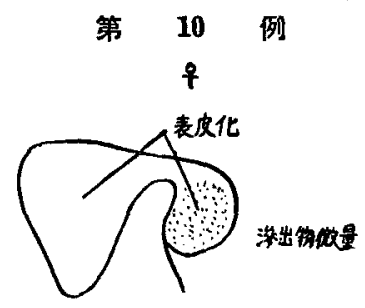

病理組穖学的所見
(1) 鼓
室 (写真 11)

治澺部 (外耳道に移行する部分)：記載省略

病栄部（鼓室岬に相当する部分）：表面は全て表皮に

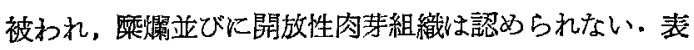
皮及び表皮下゙固有層の共に肥厚している部分では，盾化 並びに乳頭形成なく，基底膜む不明である・固有層では 一部小円形細胞の浸潤高度で， Russel 小体を認め又血 管む中等量に見られる・他の部位では上皮下は線維芽細 胞が中等量，線維細胞が軽度に堌生している. 又固有啳 の梁層は撚㝗様である。

他の部位の完成した表皮下固有層の梁部にかなり大き なチステがある（写真 12）、チステの内壁は屚平上皮に 被われ，上皮值下の基底膜は不明瞭で，その外周を密な 結会織が困繞する・チステ内腙见は荟出性物質，多核白 血球及び脱落上皮細胞が䜑められる・チステより表皮に 向亏固有㬝及びその周辺は線維細胞の増生著るしく，細 胞漫潤を認めない，血管は中等量に散在している。

ワイゲルト弾性線維染色ではチステの全層に弾性線維 を認めない。

第 11 例 M. O. 22 才 ㅇ

小光の頃から右耳漏を認め，昭和 28 年に根治手術を 
受けたが治瘾しない。

臨床所見：乳突部の大部分は表皮化しているが，乳 様洞入口部茂らら鼓䇺全体にかけて肉芽様となり膿汗が多 W.

再手術：昭和 32 年 10 月 Mayer 法を施行. 術後 42 日目に完全に表皮化した。炤和 33 年 7 月現在完治して いる。

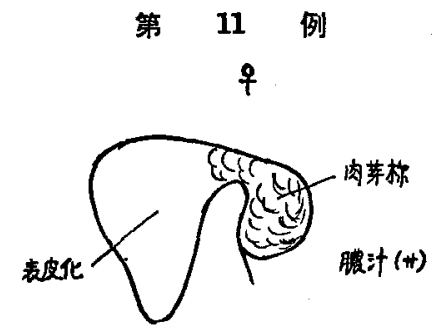

病理組織学的所見

(1) 鼓 案

治痛部：記載省略

病栄中心部：標本の辺縁冾癒部から中心病栄部に向 つて次第に組織は肥厚し隆起している.中心部の粘膜は 半球状婊面突出するかあるいは緩やか炕起伏してい る・上皮は殆ど脱落していて上皮直下の基底膜る不明瞭 であり，固有層は梁部に至る迄強く炎症泩に肉苏化して いる.この肉芽腫に隣接して表面不平滑凹凸な部位では 2 層の立方上皮が僅かに残存しているところがある・こ の附近の固有層は小円形細胞の浸潤強く，淋巴結節様の 淋巴球集積を形成するところがある。この淋巴球集積を 狭えで 1 側に变性した 2 列円柱上皮に被われた内腙の広 い凹陷がある・この内腔の深部には粘液樣物質とこれに 包含された脱落上皮細胞及び上皮性巨細胞が認められ る. 凹宿の粘膜表面開口部では上皮は大部分脱落して， 僅かに残存するものは多列队柱上皮である・又四樎の上 皮直下には基底膜を認め難い，一方淋巴球集積部の他側 には固有層梁部にかなり大きなチステを認める・チステ

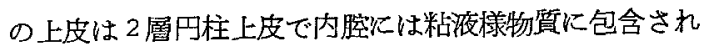
た脱落上皮細胞と多数の多核白血球索認める。

病巣周辺部：中心部加周辺へ向う飞従い粘膜は消 失し遂次表皮が現れて来る。この表皮は粘膜との境界は 鋸歯状々なつているので，この部分では表皮は断続し島

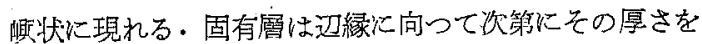
減じ，中等度の出血及び小归形田胞浸潤と軽度の毛細血 管の新生を認める。

固有層梁部に小さな 4 〜 個の 長棈円形チステが 表面
に並行しているのを認める、その上皮は単層立方上皮 で，内䐩沉巨細胞あるいは脱落上皮細胞者有するものが ある. 㕛この附近の浅層から深層にかけて，ほ心1列に 亚ら大小 $3 \sim 4$ 個のチステを諗める.内壁は 2 層の立方 上皮に被われ，内腔には巨細胞(写真 18) や脱落上皮細 胞を認める・巨細胞のあるるのは多核白血球を嗆食して いる。

病巣粘膜に接する部位に単層の立方〜円柱䋐毛上皮に 被われた四宿があり，内腔には粘夜棁物質包埋された 数個の巨細胞と多数の脱落上皮細胞灰び多核白血球を認 める.この横断面は円形で一層の繊毛円柱上皮と豊满な

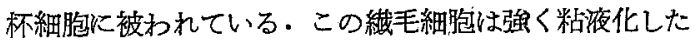
杯細胞によつて圧迫され著るしく細長くなり，核も文細 長くなつている・杯細胞の核は濃縮して一側々偏在し， 雾々不明膫となつている (写真 21).

凹楩の近くの表皮下に大きなチステがある。これを連 続切片で追求すると，固有層深部から表皮内へ達する複 雑なりのである事が分る(写真 13).内壁は1〜2層扁 平上皮に被われ，その票富な内容物は梁部から表層へ向 つて流動している・しかし表皮内に達したチステは僅か 1〜2缕の扁亚上皮細胞に閉踑されて表面に破れる事は ない。近い将来こ〉が破れて内容が排出されるであるう 事は容易に想像でさる。テステの内容は粘液梯物筫とこ れに包埋された多数の巨細胞脱落上皮細胞及び多核白血 球である.

このチステに接して閉鎖性肉芽腫がある・これ等の固 有層の梁部には厚い、盤痕組織が認められる。

第 12 例 S. O. 20 才。

8 才の時から右耳漏があり, 昭和 28 年根治手術を受 けたが治療せず耳漏を訴光る。

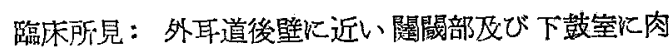
芽様組織を認める他，表皮化している。

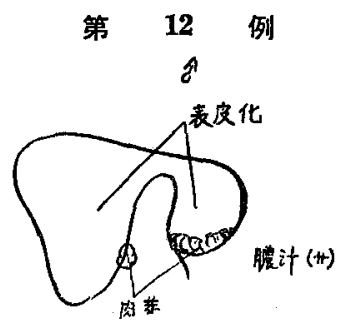

再手術：昭和 32 年 12 月 Mayer 法を施行・術後 45 日目に完全に表皮化した。

病理組織学的所見 : 


\section{(1) 閣閥部の肉芽梯組織}

\section{治㙩部：記載省略 ('写真 1$)$}

病栄中心部：表面は上皮を全く欠除し開放性肉芽随 を形成している，基底膜の存在も明らかでない．

病栄部のほ上゙中央に変性著るしい重㬝円柱上皮に被わ れた管状の凹宿を認める・内腔は空虚で表㬝に近いとこ ろは猴窄し，この部の上皮は脱落しているところが多 W.

固有層は小円形細胞の浸潤が高度で持に Russel 小体 を認める・文中等量の毛細血管と高度の出血がある。

病栄周辺部：記载省略

(2) 鼓 室

治脎部：記載省略

病巣中心部：大部分はや小肥厚した 重畨扁平上皮に 被われるが，その至るところに一部空胞化した 2 列織毛 円柱上皮に被われた凹宿を参数認める・四宿々山宿の間 の上皮は大部分変性著るしく，構造も不明となり，基底 膜も明瞭でない。これ等の凹陥の形態は一㥞でなく，一 部は狭細な哚く進入した管状をなし，一部は深い瑇を形 成し，又他の部では口の小さい檑状となつて更にその梁 部にあるかなり大きな扁平なチステと交通している，凹 楩の内腔江一部に少数の脱落上皮細胞が認められる他は 一般に空虚に見える(写真 7,8$)$.

この固有層は小円形細胞の浸潤高度で，結合組織夜び 血管の增生著るしく，潹部は線維細胞及び線維の増生が 著るしい。

病巣周辺部：中心部に近い表皮は肥厚し角化が認め られるが乳頭の形成は良好でない，固有層は結合組織袡 で線維細、包の増生が著るしく，血管も乏しい，中心部の 四宿の延長がこつに数個の楕问形の断面を示し一見チス テのように見える・表層に近いるの土附近に小円形細胞 の浸潤が高度で，深部のものでは極く軽度である・その 内腔は空虚に見える . 即ち四陷㥀有層内を梁部へ向つ て，複雑炕迂曲し乍ら父分彼し乍ら進入している。

籍 13 例 Y. O. 27 才

5 才頃より左中耳炎に羅り，5才，12才，25才の洔と 3 回手術を受けた。第 3 回目の手術 (Mayer 法) 後一 旦完全に表皮化したが，その 2 年後再び微量の耳漏を認 めた。

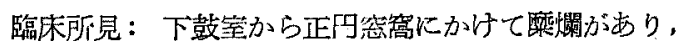
僅が湿閏している他は，表皮化している。

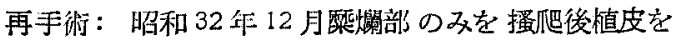

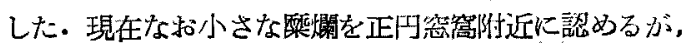

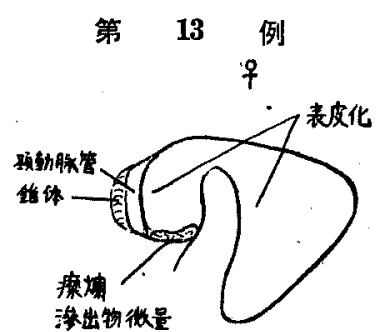

殆ど乾燥している。

病理組織学的所見

治癒部：記載省略

病兽中心部：こつは粘膜であつて，一部に残存する

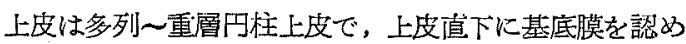
る・固有層は非薄であつて結合組織は一般に蹯である。 小円形細胞の浸潤は殆どないが，ところにより固有層の 浅㬝に極〈軽度の浸潤を認める。こつでは毛細管の新生 が盛で，附近に多核白血球の遊出を数個認好る.固有㬝 の深㬝は線維細胞及び線維の増生を軽度に認めるが，小 円形細胞の浸潤はなく血管に乏しい。

病巣周辺部：表皮に被われ，中心部粘膜との境界は 明䐲である。その部の表皮はや〉肥厚している，固有層 の浅屠は結合組織柾で小円形細胞の浸潤を極く軽度に詒 める・深層では細胞浸潤なく軽度の維線細胞之線維增生 を認める。

表皮下に多列瀻毛円柱上皮に被われたテステがあり表 面に開口している。開口部は狭く，チステはロの小さな 壱状となつている，内腔の琹層に近いところに脱落上皮 細胞を含む澇出物を認める・ワイゲルト弾性線維染色で 弾性線維を全層に認めない。

第 14 例 Y. K. 23 才 9

7 才の眝に左中耳炎に䍜患し，聴保根治手術を受けた が 4 年後江再発し，昭和 32 年 2 月根治手術を受けた。

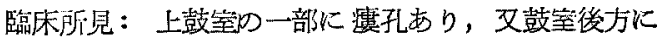
肉芽槉組織が吅つていずれも少量の排脤がある・他は洨 皮化している。

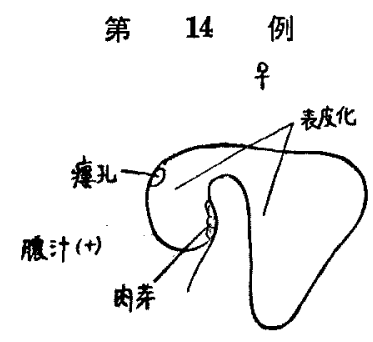


再手術：昭和 33 年 2 月鼓室を蛋爬後植皮し，術後 24 日目に完全に表皮化した。同 33 年 8 月現在完治 してい る。

病理組織学的所見

(1) 下 鼓 室

治澺部：記載省略

病栄中心部：病的粘膜であって，大部分上皮は脱落 てている・僅が残存する上皮は变性せる1層の立方上 皮からなる・数個の深い凹楩があり，1＼cjkstart数層の立方上 皮に被われているが，一部に繊毛上皮を認める・固有層 には線維細胞並びに線維の增生が盛であるが，小円形細 胞浸潤並びに血管の增生の著るしいところむある。

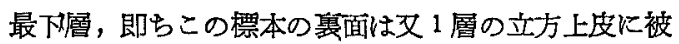
われて扣り，上皮緗胞は大部分脱落している。これは表 皮下 Hohlraum の内壁の一部を 形成していた上皮であ つて，ところどころ浅い四樎を示し上皮下に軽度の小円 形細胞浸潤を認める. 文病栄周辺部近く1個の深い凹 宿があるが，これは 2 層立方上皮に被われ切片によって はその断面がキステ樣に見える。

病紧周辺部：厚さの不平等な表皮に被方れ，病巣粘 膜とは劃然と堺されている・角化は著明でないが乳頭の 形成は良好である・標本のほら゙中央に，基底膜の著明な 多列繊毛上皮飞被われた凹宿之，基底膜の不明瞭な 2 列 緎毛上皮に被われた凹陥之が乳嘴状突起物を狭み両側に 認められる，乳嘴状突起の表面は表皮に被われるところ と欠如しているところとがある・この周辺には中等度の 小円形細胞浸潤があり，線維の堌生交び毛細血管の新生 が共に著しい，固有層梁部に 2〜3のチステ様 となつた 凹陷の断面があつて，連続切片で表面に開口している事 が分る・その内面は 2 層瀻毛上皮に被われるが，織毛の 大部分は失われ又細胞は空胞化しているものが多いこ れ等の内腔はいずれも空虚に見光，周国に軽度の細胞浸

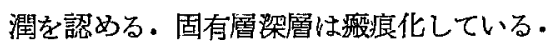

(2) 鼓至前方（愊孔の部分）

病宩中心部：䧹孔の壁の一部には $\mathrm{I} ２$ 層の立方上皮 に被われ，複雑に分肢した染い凹䧩がある.その上皮は 大部分脱落し，残存せる上皮は变性に宿つている. 世楩 周团の固有層には小円形細胞の浸潤が強度で血管新生も 著るしい，乞の周辺には線維細胞及び線維の增生盛で， 細胞浸潤も中等度に認好られ。

病巣周讱部：登育良好な表皮に被われるが乳頭形成 交び角化は軽度である.この表皮は病栄中心部々は離れ

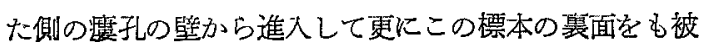

うている.従つて標本は両面共表皮に被われている・裹 面の表皮は表面の表皮に比へて発育覀く，韭薄で殆ど乳 䫄を誌めない. 病单中心部との移行部では表皮は上層か ら㴬次消失して菲薄となり，粘膜に移行している.固有 賣は搬痕化の傾向が強いが一部に中等度の小円形細胞浸 潤を認める・いか䛉してこのような庵孔を形成したかは この標本では明らかではない。

(3) 下鼓室の骨

骨梁間の軟部組織は線維苯細胞及び線維細胞の增生が 著るしいが，血管に乏しく細細浸潤を全く認めない，又

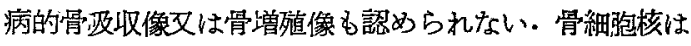
澧維に楩り，县小体の一隅に压排せられているすのを屡 々認めるが，骨細捣の消失はない，又骨筫板に特別の变 化はない。

第15例 T. W. 19 寸 8

4 才の時に右側根治手術を受け以後時々耳漏があつた が最近は停止している。

臨床所見：乳午部は耳坧で充满しこれを除去してみ ると迷路周国部は少しく肉莱様に見え, 鼓室は表皮化し ているが全体が著明に浅くなつている。

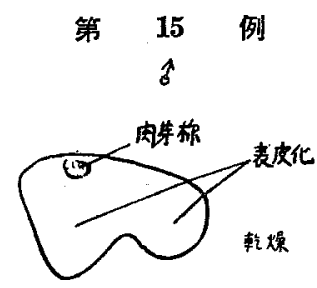

再手術：昭和 33 年 3 月再手術を行つた・迷路周四部 には浮腫状の病的粘膜を有する小蜂巣を多数認め，鼓室 の表皮化した組織下に迷路周团及び耳管に通ずる大きな Hohlraum を認めた・単純耳管搔爬後植皮を行い，術 後35 日で完全に表皮化した。

病理組織学的所見

（1）鼓室から乳样洞入口部にかけて

表面は非薄で角化著明な表皮によつて被われる.固有 層は線維化し細胞浸潤を認めないところどころに立方 上皮に被われた小さなテステを認める（写真2）が，卡 の周辺の細胞浸潤は極めて 軽度である. 最下層に $1 \sim 2$ 譄立方上皮を諗めるがこれは肉眼的汇認められた Hohlraum の壁の一部である.

(2) 耳管入口部附近

表面は乳㥆洞入口部の表皮よりや〉肥厚した表皮に被 われるが，耳管入口部に相当する部分では久如し掼孔を 
形成している．固有層は著るしく肥厚し今迄に見たもの \5 6 倍に達している.韯皮值下には線維化した薄い 層があり，この下に小円形細胞の浸閏した渵が見られ る.この下部から梁層にかけては線維細胞が著るしく增 生し，ところにより線維化が著明となつている。

固有層の至るところに注上球形で大小様ななチステを 10.数個認める・チステの内壁は色々で，2層立方上皮あ るいは1 層の円柱〜立方〜扁平上皮に被われる．内腔に はいずれる粘液様物質を有するが，大きいチステではは ざ内腔を充満し，小さいチステでは少量で紐状又は網状 となつている・大さいテステには霓々上皮性巨細胞及び 脱落上皮細胞を認める・チステ外周け線維化し小円形細 胞浸潤を認めないしかしチステとチステの間には淋巴 結節様の淋巴球集積を認めるところがある・これらのチ ステの一部は互に連絡交通しているが，表面に開口して いるるのは全く䍿められない。

3）病理組織学的所見の小括

(1) 治 痖 部:

肉腿的に畭懆し白色で光沢を有する表皮化した治拯部 は，組織学的にもほよ゙完成した韭薄な表皮によつて被わ れている(写真 1).

即ち，最表層は角化し，屡々淡明層を欠如して顆粒尿 に移行する．顆粒譻の細胞は大部分ケラトヒアリン顆粒 を包含している・有棘層は肥厚した表皮では厚く数篔か らなるが，菲薄なるのでは時に 1〜2層の細胞からなつ ている.この層は通常細胞間隚及び細胞間橋を䜑めるが， 時に不明瞭な場合がある.円柱形の基底細胞には色素顆 粒を持つむのと持たないるのとがある・上皮值下の基底 膜は一般に H.E. 染色では不眀瞭である.

乳頭の発育程度は色々である，即ち乳頭が長く表皮基 底部の凹凸が著るしく深いるの，乳頭が狭く表皮基底部 の凸部が互に密接しているもの，乳頭が広大で表皮基底 部の凸部が細くなつているるの等である・矢乳頭の全く 形成されていない場合もある・表皮下固有層は菲薄で結 合組織は著明に増生し愿々瘕痕化している・稀には秥合 組織の蹯な場合功ある・こつには細胞浸潤は全く無く， 血管は一般に乏しい：これ等の固有層は骴膜を介して骨 に密着している. 毛, 毛包, 皮脂腺及び耵輘腺を欠如し ているが, 2〜3の標本では皮脂腺る認めた（写真 23）. これは植皮によつて移入されたるのである・時涸有層 内閉鎖性粘膜チステを認める事がある（症例 2,15，写 真2). チステは病巣周辺部に見られるチステと異ると ころはない。
その他，一般外皮に見られるような脂肪組織を含む皮 下組織は全く認ぬられない，即ら，治撚部は表皮と結合 組織（固有層）からなる外皮によつて被われている。

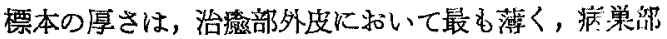
に近ずくにつれて次第に肥厚し，病巣を形成する粘膜部 は最も厚くならている。

(2) 病栄周辺部:

治療部外皮か病巣部に近ずくと，各の表皮は次第に肥 厚し治癔部の表皮に比し厚さは数倍に達する.病巣周辺 部の表皮は一般に表皮としての構造を失う事はないが， 角質層はや小厚くなり有䗲層の細胞が变性空胞化する傾 向が見られる・稀には角化，ケラトヒアリン顆柆共に不 明瞭で，この上皮中に多数の多核白血球の遊走を認める 場合がある(第 5 例, 写真 22 ).

病巣粘膜との移行部では，一船に肥厚せる表皮は突然 消失する・即ち，表皮はこの移行部で垂直に切断された ように見え，あるいは基底細胞が楔状に鋭利に病栄粘膜 固有層内へ進入して終つている. 又時には表皮の上層か ら順次脱落し乍ら消失して行く場合もある.

表皮下固有層は著明に肥厚し，その浅層には種々の程 度に小円形細胞浸潤を認める・しかし病巣粘膜部に比へ ればその程度け妈い，固有層深層は通常線維化し，屡々 洀癔佯となり円形細胞の浸潤は認めない，血管は中等量 に存在する。

表皮下固有層に認められる著明な所見として屡く開鎖 性チステを認める・この他に病巣粘膜部から由来する粘 膜凹陥の延長がチステ様の断面となつて認められる・こ の両者は連綕切片によつて始めて区別される・

このように病巣周辺部の表皮は病巣粘膜部との移行部 でその伸展を停止し，表皮下固有層は多分に病单粘膜の 影響を受けて，多かれ少かれ炎症の波及している事が分 る.

(3) 病栄中心部:

術創の肉眼的に肉芽又は徆關として見える部分には， これを組織学的炕みる全て曼性㷋症を伴う病的粘膜を 認める・これ等の病的粘膜の形態は次のように分類され る(第 12 表参照).

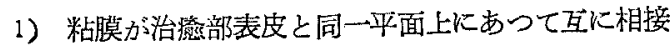
し，ほડ゙同じ高さにあるもの (写真 3 ).

2）粘膜がこれに接卞る治翁部表皮より隆起して丘状 乃至半球状となり，遂には孚嘅状となるるの。

a) 絬膜面が平なもの (导真 4).

b）粘膜面に更に湾入部を作り，不平となるもの（写 
第 12 表

口表皮 -...- 䊀膜上皮

(I)

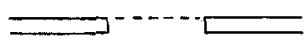

(2)
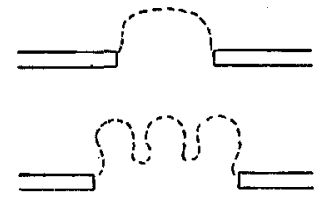

c.

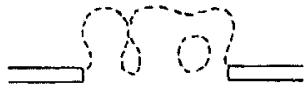

(3)

a

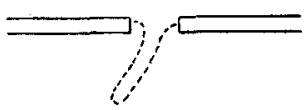

t

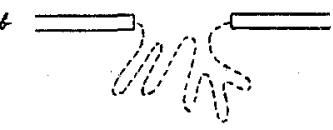

c

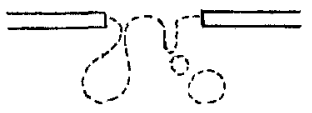

(4)

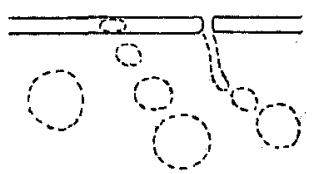

真 5).

c）乳嘴状突出部が互に撩着して，根部にテステを形 成するもの.

3）粘膜がこれに接する表皮面より下方に梁く上皮下 固有㬝付へ凹陥しているもの.

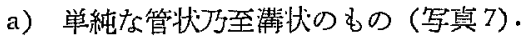

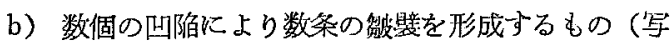
真 6 ).

c）凹楩の開口部が狭くなり，盲端が㧓大してテステ を形成する るの（写真 8 ).

4）斐皮下沽有磨，時には表皮外にテステを形成する もの（写真 $2,3,4,6,10,11,13)$.

a) 潗孔を有与るもの.

b) 閉鎖性キステ .

粘膜は一般に著明に肥厚し，周辺部並に治囦部に比し

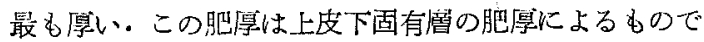
教る. Brock4) (1925) 並びに Marx ${ }^{30)}$ (1938) は慢性
非耳炎の粘膜肥厚は上皮下結合組織の 肥厚によるもの で，骨膜㢞は变化しないと云らが，私の所見むこれと良 く一致している。

粘膜上皮は変性脱落するすのが多いが，鼓空玾では単 層〜多列円柱，2層立方上皮で，これ等加的重層扁平上 皮への移行像が諮められた。これは明らかに慢性炎症に よる上皮の化生の段階を物語つている.下鼓室です単層 站加ら重層円柱上皮への移行像を認めた他, 多列〜重 闃円柱上皮る認められた，耳管入口部附近では多列〜重 周円柱上皮を認めた・鼓空後方では算層立方，単㬝〜2 列円柱, 重周円柱上皮を認めた・迷路周目でけ多列〜重

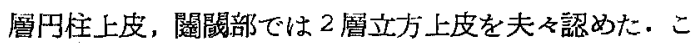
のように病巣粘膜の上皮の形態は色ヶで一定していな ᄂ.

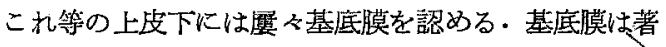
明に肥等しているあのあるいはところどころ不明瞭とな つているもの，文は全く不明となつているものがある。

上皮下固有層はいずれも種々の程㹣に肉辈化してい る・即ち，血管，結合組織の增生が極めて強く小円形細 胞の浸潤が著るしく高度である，肉芽化の強い程表面の 㦀起及び突出が著明で，表面には線稚素と共に白血球等 か泭着し，固有㞗浅尿は血管に富み，沏層は結合組織線 維が增生して開放性肉芽軣を形成している（第8例，写

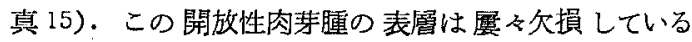
が，材料採取時に人工的に萑起されたものが多いと思わ れる. 文病单の広い程復雑な乳嘴状突起を形成する傾向 がある(第 1 例, 写真 5).

このような開放性肉芽腫の他に，時に閉鎖性肉芽腫か 認められる(第9例，写真 14). 即ち，この中心部は変

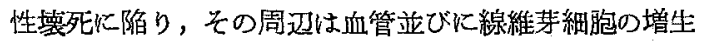
が著るしく，更にこれを結合組織線維の䍛が閉鎖珄に取

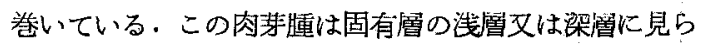
れるが，連続切片で追求してみると表面に破れる事なく 注ざ球形を呈している雪が分る。

（4）粘膜四宿とチステについて

病宩中心部を形成する病的粘膜には殆ど例外なく，陰 凅样の四陷文は閉鎖性テステを認める。

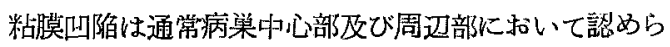
れ，表面から固有層内へほ心゙表面に垂犆に，時に斜めに 進入する・表面の粘膜上皮は脱洛しているものが多いの で，裴面の上皮と凹陌内面の上皮との移行像は殆ど認め る事ができない，しかし上皮下基底膜は表面から凹楩上

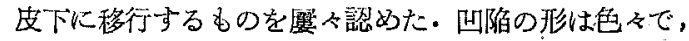


单なる管状のもの，裂溝状のもの，これ等が梁部で簡単 に分岐するもの, 更に複雑に多方向に分岐与るもの, 又 は開口部が狭く内方に広、霊状のもの，あるいは開口部 はや〉広く固有層内人内面汇山凸を作り乍ら狭くなつて 行くもの等である. 四宿の内面を被ら上皮は，単〜2層 扁平，単層立方，単層高円柱，2＼cjkstart多列円柱，縉毛円柱， 重居円柱上皮等で時に杯細胞を見る事がある.々の外周 に屡々基底膜を認めるが，基底膜は固有層の続合組織と 接着しその外周に特に被膜を認めない，文ワイゲルト弾 性線維染色によつて弾性線維を殆ど諮めない，回宿の周

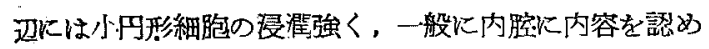
ないが，一部に粘液様物買，脱落上皮細胞及び白血球等 を認める事がある(第6 例). 凹陷の横断面は屡ネキス テ様に見えるが，これを連続切片で追求すると表面に開 ロして和り叫宿である事を確め得る・喵宿は文表面に近 い部分が狭窄し又は開鎖して完全なチステを形成する傾 向がある(写真 8 ).

典型的な閍鎖性 チステは病巣中心部及びその 周边部 飞，又時には治劄部の表皮下固有尿染部に認められる。 その数は最む多いむので 1 切片に 15 個を数えた（第 15 例)・大きさは色々で固有層の高さの半分を占めるるの から. 赤血球 5〜6 個を満たす小血管程度のもの迄ある. 形はほじ円形〜卵円形〜長雜円形で，時には種々の突起 を有する不規則な形を示するのるある・上皮は単〜2㬝 扁平，単〜2 層立方上皮で基底膜は不明膫である，その 外周は多く著明に線維化して被膜様となり，矢の周辺の 小円形細胞浸潤は一般に軽度である。これ等のチステは 互に交通して数珠状双は葡萄状となる傾向を有する. 又 互に交通して表皮内人達し将に表面似破裂女んとするる の屯ある(第 12 例，写真 13).チステの内腔には通常粘 液様あるい沟質性物質と，これに包埋された2〜多核 の巨絧胞, 脱落上皮細胞, 時化多核白血球及び大学核細

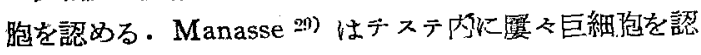
めたと云い，Brock 4)はとれ程多くはないと述べてい るが私は Manasse と同様に屡々巨細胞を認めた・文弾 性線維染色を行つた標本ではチステ壁には殆ど弾性線 維を認めなかつた・

(5) 鼓室腺 (Gl. tympanica) について

私は唯 1 例であるが標本の数カ所汇粘液性腺管の横断 面を認めた（第 5 例，写真 20). 即ち，腺管の内面は円 柱形上皮細忽に被われ，H.E. 染色ではこれ等の細胞は いずれも核上部が透明な空胞によつて充されている・通 常 1 個の核は細胞基底部の 1 側に圧排され，㠰胞の強く
充盈した細胞では核は屡々濃樎に宿り，核の表面には空 胞による压痕が認められる・この所見は唾液腺等の粘液 細胞の所見之良く一致しているので，核上部にみられる 空胞は粘陮空胞でこの 細胞が 粘液細胞であると思われ る. 粘液細胞層は結合組織からなる固有膜に接着し，こ れ等の間に筋上皮細胞様の細胞がところと゚ころに見られ るが，これを正確に同定する事はできなかつた。この腺 管は連続切片によつて盲端に終ることが分る・成書に上 れば鼓室腺は短管状腺で，その長さは約 $0.1 \mathrm{~mm}$ である と云う・私の所見でる短い管状腺であることを認めた・

粘液腺管のあるすのはチステ様となり，腺上皮細胞 は一部立方〜扁平化し，管腔内に 4〜5核からなる巨細 胞を認める・又ある腺管では腺上皮細胞の一部が脱落し て，管内壁には結合組織細朌からなる固有膜が露出し， 管脘:内にはこれら脱落上皮絧胞が融合して巨細胞を形成 していると思われる像が認められた。

粘液性腺管と一見よく似た所見で，杯細胞と㵶毛上皮 細胞之からなる円形の管肪浡認めた（第１2 例, 写索21). この管腙の内面は著るしく肥満した杯細胞と，その間に 介在する著るしく細長く圧排された紷毛円柱上皮細胞と に被われている・文先の間にところでころ H.E. 染色で 濃染した隌調な上皮細胞（Stiftchenzellen）が見られ る. Eimer (1868) は2 個の杯細胞は互いに接すること はないと述へ，北顺高橋は虫垂に捣いて同様な所見を 認めている(北川と高橋 ${ }^{20)}$ 引用). 私の所見あ同様で， 粘液性腺管と爁別する上に一つの良い目標となつた。徉 つてこの管腔は瀻毛上皮に被われた凹楩の横断面で， Hajek 12) の云うょうに織毛上皮細胞が炎症によつて杯 細胞に転化した像であろらと考学られる・

(6) 骨組織の变化について

病栄部の解剖学的な関係から, 組織学的㭘索に必要な だけの充分な大きさに病巣直下の骨洼を削除する事は極 めて困難であつた，従つて骨組繶の変化について検索し 得たものは第 2，3，7，14 例の 4 例である. 第 2 例は耳 管入口部骨壁からとり，他の3 例はいずれる下鼓室の骨 壁から採取した・

骨梁閏に介在する結合組織は頙な所むむるが，一部病 宩粘膜の炎症の影響を受けて線維芽細胞並びに線維細胞 が堌殖し，結合組織は密となり小円形細胞の浸潤を認ぬ る所がある(写真 17).

一般に骨には著明な病的変化を認めない上記結合組 織細胞が堌殖して結合組織が密となつた部分に接与る骨 には，屡々Umbau 及び明らかな骨增殖像を誌めるが 


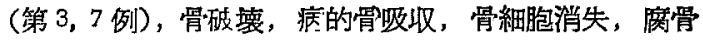
形成等の病的变化は全く認めない，骨墥殖は層状い骨增 殖であつて，ェォジンに淡染する板状の層即ち類骨質と して認められる．時には奶弱骨細胞を有する新生骨を認 める・これ等はアザン染色により青染し古い骨とは明ら かに区別される・骨梁面に著明な骨增殖を呈するるの む, 骨䯣腔には変化を認めない。

第 2，14 例は骨には全く病的変化を認めない. 即ち，4 例叶 2 例は Manasse ${ }^{29)}$ の云5 rein produktive Form に相当すると考党ら机るが，彼の destruktive Form に相当するすのは全く認められない。

\section{5. 文献的考察及び考按}

1）根治手術を受けた側頭骨の病理組濰学的研 究について

币耳耳根治手術後の術創の治痖機転を理解するために は，根沿手術を受けた側頭骨の病理組織学的研究が最も 重要である事は論をまたない。これについてはすでに 1898 年 Zeroni ${ }^{58)}$ とよつて詩細な研究が報告され，そ の後も興味ある報告が相㳄いで発表されている・しかし 我国ではこれらの報告については余り知られていないと 思われるので，こフにその概要を述べてみたい. Zeroni 58）の報告した 1 例は 根治手術後 6 週間で腹膜炎により 死亡したもので, 死亡前術創全面は表皮化し唯鼓室後方 に淤皮があつて，時々耳漏があるのみであつた。組織学 的には，鐙骨附近には表皮なく1層の低い円柱上皮に 被われ，その深層の肉芽組織内炕さきデテがある。 チステの上皮は表層の円柱上皮と同様で，内腕淿血球 を有している，その周囲に細胞浸潤か強く，管は全く正 常であつた・第 2 例は術後 2 年で膿血症により死亡・術 前の所見では全創面は完全に表皮化していたが，組織学: 的には鼓室の迷路空筒附近及び耳管入口部で表皮と骨壁 の閂に Hohlraum があつて，円柱上皮に被われ，その 周囲には资症は全くなかつたと云う。

その後 Ruttin ${ }^{45)}$ (1908) は根治手術後の慢性中耳炎 25 例を報告し，上皮に関する最も著るしい変化はチス ラ゙，チステ捸腔及び盲垔形成であると述へ，これ等をそ の場所と形成機転によつて後述の如く 4 型に分類してい る。

又 Lange ${ }^{22)}$ (1910) は4 個の側頭骨標本について報 告している.第1例は術後 4 週で死亡，半規管，卵円空 㖞附近の表皮下に破裂せんとする Hohlraum 乃至チス テがあり，鼓室内壁にも耳管へ通ずる Hohlraum があ る.第 2 例は術後 8 週で死亡，鼓膜が鼓室岬に簿着して
鼓堂を上下に二分し，下の部分は粘膜に被われ耳管に向 つている.第 3 例は 1 年半後に死亡, 鼓室に遺放粘膜が あり炎症強く耳管は開放している.第 4 例は完全に治つ た例で，鼓室は鼓膜により二分され，下方は開鎖して耳 管に通でてお正常粘膜に被われ，深部には少数のチス テがあると述べている。

Neumann ${ }^{34)}$ (1929) は術後6年, 21 年, 4 年，4日 の 側頭骨について，迷路空窩又はこつより耳管にかけ ての表皮下に多数のチステを認めている・一方鼓䇪壁に は静止形となつた Arrosion を諗め，全く正常な表皮の 下に Osteoporose を証明している.そして術創は常に 休止する事なく活磁な Umbau と反応機転とを示すむ ので，全く正常な表皮の下にもこのよらな所見がある事 が術後の迷路炎発生を説明すると述へている。

Brunner 5) 6) は 1931 年及び 1954 年に 11 例 12 側頭 骨について報告した・内8 例は著者らによつて手術が行 われた・これ等を(1) 全創腔が重層扁平上皮に被われ るもの，(2) 円柱～立方上皮に被われるもの，(3) 両種 上皮の混在するものとに分け，(3) が最も悪く，(1)が 理想的であるがこれる永続的のものでなく，再感染中真 珠腫再発を茩起する事があると遮へている。

近年化学潦法の進歩之共に根治手術後に死亡する症列 は稀となり，術後の側頭骨を検索する袎会が得られなく なつたために，これに関する報告は殆ど見当らない，僅 かに土田等 59) (1956) が術後 2 月不び 1 月の 2 側頭骨に ついて報告しているのみで，最近では主として再手術に よつて得た標本についての報告が多い。即ち，仁保(正)， 石川 16) (1951) は根治手術後に鑊体手術を行つた 1 例に つ、て，その病栄部を組織学的に検し，住保 (三)，吉 尾 ${ }^{95)}$ (1952) は根治手術後の5 例について主として錐体 部の組織学的検索の結果を報告している・一方 Withal$\mathrm{m}^{54)}$ (1955) は術後の持続的な湿潤は慢性湿奏々 同様 な所見によるとし，これを組織学的に証明している・又 Rambo ${ }^{42)}$ (1956) は5 年間 2,000 例の 側頭骨手術 (開 答術又は中耳炎）の術創から 52 例 $(2.5 \%)$ のチステを みたと述べている（註，但し肉眼的に認められるチステ のみ).

2）術創の治癒状熊並びにその再発について

根治手術後の術創は特殊な術式を除いて，外耳道浽開 放された全創面が抵抗力の強い外皮によつて被われる事 が理想である・そのためには衍創面に病的であると正常 であるとを問わず，粘膜が存在するのは望ましくないと いりら事は論を待たない。 
㠰加し，手術によつて鼓室周辺から粘膜を完全に除去

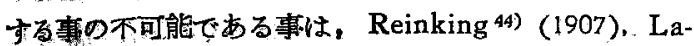
nge 22) (1910), Wittmaack 65) (1922), Brunner 5) 6) (1931) 等の迡べている所で，この事は又鼓穻の局所解 部学的な特殊性から容易に首貢されるところである。

しからば粘膜の遺残した衤の理想的治痖とはいかなる 形態をとるか.この事は Zeroni ${ }^{58)}$ (1898), Ruttin ${ }^{45)}$ (1908), Lange 22) (1910), Neumann 31) (1929) 等の報 告によつて明らかにされている・即ち，遗䂝粘膜は特に 迷路空管附近无び耳管入口部附近において，表皮と骨壁 との間に閉鎖性のチステとして封入され周团に炎症のな い状態である・私の定例です（第 4,15例）長期間臨床 的には治猗状態にあつた部分の表皮下に屡な閉鎖性のテ ステを詰めた（写怘 2 ).

このように閉鎖性チステを形成して沿療する他，Lange 22) 23) の推笑するよ5に，残存鼓膜を迷路壁に痖着 させ所謂膜性閉鎖を計つた場合にも臨床的には治婈状態 となり得る・この場合は迷路壁に殓着した鼓膜又は新生 膜羕物によって鼓室は上下に二分され，下方の下鼓室は 粘膜上皮に被われた Hohlraum を形成しこれが耳管に 通ずる帚になる・

以上の事から明らかなよらに，根治手術の術創が治痖 するため济，外界に開放された全術創は抵抗力の強い 外皮に被方九，耳管粘膜及び遗残粘膜は外界に直接露出 きれる事なく表皮下に各る固有の腙双はチステとなつ て、孤立するかあるい仕耳管へ通ずる事が必要である。 換言す妇は，術創においてい外皮と粘膜とは同一面上に 相接してはならない，例え炎症のない粘膜であつても中 耳腔の粘膜は外界の刺㦸に䇏して函めて抵抗力が弱いの で，将来必ず感染をさたして肉芽を形成し排膿する事は 明らかである. 又 Reinking ${ }^{44)}$, Wittmaack ${ }^{55)}$, Brunner 5) 6) 等の強調するよ5K，表皮之粘膜上皮との拮抗

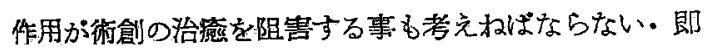
ち，粘膜は湿潤を要し外皮は乾燥を要する・又粘膜の炎 症は表皮の角化落首を促准し，表皮の落㻺は粘膜の炎症 を堌覀せしめるといら悪循環をきたすからである・

この尋は近時とみに盛になつた鼓室成形術後の治癒形 態の上にも重要である・即ち，外界に懪露された外耳道 に開放する術創は全て外皮に被われ，新生鼓室は旧来の 䞚宔粘膜又は耳管粘膜の伸展による粘膜によつて被われ る事が必要で，外皮と粘膜とは互に背中合せになる事は あつても連続した面において互に相接してはならない。 しかし一方このような表皮下の粘膜チステ及は Ho- hlraum 形成が再発の原因となる事は，Zeroni ${ }^{58), ~ R u-~}$

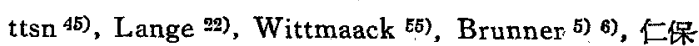

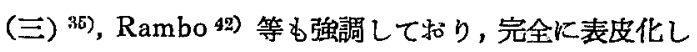
て治瘾した場合でも再発の危険は全くないとは云い得な い. 私の症例（第 4 例）にみられる臨床的に治瘉してい

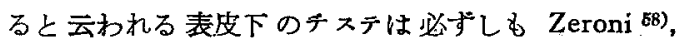
Ruttin 45) の云らような炎症のないるの১みではなく， 瘦々周囲に細胞浸潤を認め膑内に巨細胞を蔵し，又この 部の表皮は肥厚し著明な角化が見られる等，臨床症状を 示さない程度の組䄳学的変化を認めている. 又第 1 章に 述へた遠隔成綘によると，治澺例 49 例中再発したもの は6例あり，その内雪診によつて再登病单を確認した5 例の全ては鼓室後方に排䑋病亲を再発している・そして この部はチステを形成する事の多い部位であるので，再 発は長い経過の内に表皮下チステ及は Hohlraum の破 裂したためであると云ら事によつて説明される・文第 12 例にみられた固有篔内チステと連続した表皮内テステの 所見は術後の 断続的な排膿機転を説明し得るものであ љ.

一方多くの成昌に記载されてある如く，一般には根治 手術後の術創の治挜機転は表皮と肉茅との闘いであると のみ解釈されているようであるが，私の症例では资症性 粘膜から発生した图芽のために表皮化が阻害されている るのは震る諗められたが，しかし単なる肉芽のために表 皮化が妨げられている所見は全く認められなかつた・即 ら，手術後早期に㧊いては術創に発生した因芶の過剩增 生のために表皮の進展が阻害される事は勿論であるが， かなり経過した後に扣いてるなお表皮化が妨げられてい、 る埸合には，その肉芳の基底には粘膜の遗残がある事を 考えオばならない。

3）術創に存在する粘膜の形態について

根治手術後の術創に粘膜が存在する場合にその粘膜が いかなる形態をとるかといら事は，チステ以外について は砝ど論な゙られていない.

私の症例における根治手術創に存在する粘膜の形態に ついての分類はすでに述べた通りである・即ち，術後大 量の粘膜が術創に遗残されるか, 粘膜の炎症が強いか, 表皮化の力が弱いがあるいは後処置が不適当である場合 には，粘膜は術創に露出した儘で存続する事になり，時 には更に増殖して表皮化を妨げるに至る・これは私の分 類の (1) に相当する・更に自らの炎症により又は外来か らの感染を受けて肉芽の增生をさたし，粘膜面が隆起 して遂には乳嘴状となり，時には更にキステを形成す 
る. 即ち (2) a, b， c である・この群は上皮下の炎症の 極めて強いものに多く，臨床的に肉芽様組織として見ら れる事が多い.そして出物は多く膿性である。

表皮の進展の力が少しく勝れば，粘膜上皮は圧排され て上皮下固有層内一陌入して凹陷を形成する．即ち私の 分類に和ける (3) a, b c である.これは (2) 群に比 べて炎症はや〉軽く，臨床上肉腿的には应闌として見ら れる傾向があり，㳂出物は粘液性である．最後に（4）の 完成されたチステについては後に述へる。

術創にみられるこれ等の粘膜上皮は扁平上皮, 立方上 皮又は繊毛円柱上皮乃至円柱上皮等で, 単層のるのから 数層のむの迄ある. 又同一標本炕いても上皮細胞の形 態は一よらではなく婹々各々の間に移行像が認められ， 又化生の傾向を示するが多い，即ち，上皮の形には一 定した傾向が全く認められない。

慢性中耳炎の粘膜病变についての報告は多いが，上皮 の変化についての詳細な報告はない. Manasse ${ }^{29)}$ (1917) は上皮は著明に堌殖し急性の場合より靁々 Vollsaftig な円柱上皮であると述へ，Wittmaack 56)（1926）む高 い繊毛円柱上皮でその細胞は粘夜变性に陷つていると述 ベている程度で，円柱上皮又は重層扁平上皮以外の上皮 そついては余り記載されていない。

又正常中耳粘膜についてみると，Preysing 41) (1925) は鼓室耳管口は織毛立方，耳小骨及び鼓膜の鼓公面は扁 平，上鼓室は纎毛，乳様洞入口部は立方，乳様洞は単層 扁平上皮であるが余り判然とした区別は認めないと述へ ている. その他 Rauber Kopfsch 43) (1923) には補充

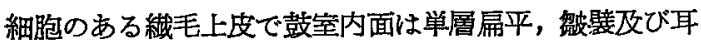
小咸は 3 層扁平で各々非瀻毛であるとし，Möllendorff 39）（1927）は立方文は扁平上皮で耳管口及び下鼓空の一 部は紻毛上皮であるとし，Maximow, Bloom ${ }^{32)}$ (1934) は算層扁平で；耳管入口部及び鼓膜輪部は瀻毛立方又は 円柱上皮であると述べている他，Jordan 17)，Cowdry?， Stöhl, Bargmann 3) 等には余り詳細な記載はない。こ のように正常中耳粘膜に颃いても上皮の形態は一定して いないよらである・それ故慢性炎症をきたした粘膜の上 皮に一定した傾向を見出し得ない事は当然であろらと思 われる，

根治手術創上皮下には慢性炎や急性堌要淀の像が著明 飞認められるものから，全く炎症の消裉した静止形のむ のがあつて，その炎症の程度には種々の段階がある・一 般的な傾向としては上述したように，粘膜面が隆起して 乳嘴状となつたるの程炎症が強く，凹陥を形成するるの
がこれに次ざ，閉鎖性チステの周边が最も资症が軽度で ある. 粘膜上皮と表皮之の移行部は多くの場合㖶然とし て怙り，一部では表皮の基底細胞層が粘膜上皮下哙い

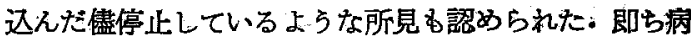
㮺粘膜によつて表皮の進展が阻止されている事が明らか に認められた。

その他，上皮下固有層に認められた著明な変化はチス テと四樎である・この而者については後述する・

文 3 例 3 標本にグラム・ワイゲル下菌染色を行つた が,グラム陽性菌は認めなからた。

4）粘膜四陷沉つて

私恃粘莫面の乳嘴状の突起の間炕できたすの及び比較 的浅い凹みを湾入 (Bucht) と名付け，腸粘膜にみられ る陰简様の陥入を四陌 (Vertiefung, Einsenkung) と 名付けた。

蜂栄等の骨面の凹凸応じて粘膜表面にできる湾入部 は正常にも見られる．しかし正常の中耳粘膜に著明な出 宿又はチステの存在を記載したものはないＢrock は) は チステは慢性炎症のない中耳粘膜には認めないと述べて いる・著明な凹陥乃至チステは病的に形成されるむので ある・古来中耳粘膜の慢性资症における特長は多数の Cystische Hohlraum の形成である事恃多くの成書炕記 載されている・私も大部分の標本にこのような所見を認 めた。文一方，慢性中耳炎に执いて粘膜上皮の凹宿があ る事は Habermann II) (1889) も述へて招り，Goerke 8) (1901), Grünberg 9) (1917), Marx ${ }^{30)}$ (1917) は耳茸 に招いてこれを認めている。

従つて私は粘膜凹宿む又，慢性中耳炎の特長であ万う と考光る・

Grünberg 9)は耳茸にみられた凹宿について，周囲の 結合組織の正迫又は率引似よって表層の近くが狭窄し， 梁部にチステを形成する事があると述べて呿る・そして 凹宿の原因として上皮下結合組織が部分的に堌殖し，そ の隆起の間に形成されるむのであると述べている.私す 凹楩からチステが形成される傾向を琶め，又粘膜面にで きた乳嘴状の突起の間に 凹陥が形成される 所見を認め た (写真 5). しかし一般的な傾向としては粘膜面火乳嘴 状の突起を形成する場合は病紧部全体が粘膜上皮化被わ れるか及は上皮が一部脱落している事が多いが，凹楩を 形成する場合怡渝部表皮が伸展して凹宿の表面開口部 に迄澾している事が多い.従つて四陌は治澺部からの表 皮の䛖展に伴つて粘膜上皮か涸有層内へ梁く陥入して形 成される場合が多いと考宇られる。 
5). 粘膜チステについて

ォステの形成は慢性中耳炎の一つの狩色に数えられて いるが，その成因については多くの説があつて一定して いない.

即ち，Politzer 10)（1876）は粘膜深層にあるものをみ てこれを淋巴管チステであると述べ，Habermann (Brock 4) の引用) は裁室が結合組織で充される際に結合組 樴の層の間にチンテができると述べている. Manasse29? （1917）は乳嘴庫状に堌殖した粘膜に括いてその乳嘴状 突起の尖端が互に癒着し根部にチステが 形成されると し, Wittmaack 56) (1926) 及び Malx 30) (1938) は溚 出物が器質化される際に器質化によつてできた組織の間 にチステができると主張している。この Manasse の説 は私の術創粘膜の形態からみた分類に怙ける (2) の種た の段階と一致するものである。

又根治手術後の術創に形成されたテステの成因につい てむ Zeroni ${ }^{58)}$ (1898) 以来多くの款告がある。即ち Zeroni は術後重層扁平上皮の進展によつて残存した円 柱上皮が上皮下一陥入し，表面に近い部分が癒着し排泄 が阻害されてテステを形成すると述べている・これは私 の分類に括ける(3) の凹陷からチステが形成される所見 飞一致し，又私の症例炕执いてはテステは世陷から形成 される場合が最む多いので私は Zeroni の説に賛成であ る. 又 Goerke 8) (1901) 及び Grünberg9) (1917) む 耳茸に扎いて四楩からテステが形成されると述べてい る.

一方 Ruttin 45) (1907) は術後に形成されるチステを 成因によって 4 型に分けている。即ち，第 1 型は鼓室粘 膜が部分的に增殖し，その增殖部が互に癒着して形成さ れるもの，第 2 型は手術によつて卵円空害内へ被いから さった粘膜により形成される。の，第了型は正円空窝内 の粘膜が増殖し不平な面が正円空膜に接する事によつて 多数のチステが形成され，第 4 型は膿のある Nische の 上を急速に上皮が進展してできるすのである・彼の第 1 型は Manasse の説及び私の (2) 型と一致すると考光ら れる. その他 Rambo:2) (1956) は Arey 1) (1936)の 説を方用して，感染父は損傷によつて破壊された固有凮 内へ上皮の突起が侵入しチステを形成すると述へ，又土 田等 ${ }^{53)}$ (1956) は中耳粘膜の有する含気化傾向からチ六 テの成因を説明せんとしている・しかし，私の観察した 内では凹樎の盲端部の上皮緇胞に特に増殖像と思われる 所見は認められないので，私の症例ではこのような成因 飞よるチステは少いと考えられる. Grünberg すむ粘膜
凹宿は上皮細胞の增殖によるものではないと述べてい る。

友田 ${ }^{52)}$ (1958) は家鬼の鼻中隔粘膜を下肢の皮下移 植するとチステを形成し，円柱上皮は扁平化すると述べ ているが，遺残粘膜が術後周囲から堌生した肉芽組織の 内に埋没された場合終にはチステを形成する事は充分考 えられる・仁保（三） ${ }^{85)}$ (1952) む術創使存された含 気蜂栄からチステを形成する場合の種をな状態について 諭じている・私の症例に打ける表皮下固有層梁く埋没し たチステはこのような成因によつてできたるのであろう と考えられるが，移行像它確認していないので確定的で はない。

一方根治手術後の術創にみられたチステが果して術後 に生じたものか，あるいは術前から存在していたもので あるかという疑問が生ずるが，Zeroni 6s）の云うように

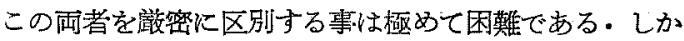
し多〈の成書 (Wittmaack ${ }^{56)}$, Manasse ${ }^{29}$ ), Brock ${ }^{4)}$ ) に明らかなように，術前のチステは多く円形又は卵円形 で稀に長楕円形のものが認められるに過ぎない．従つて 私の症例のように非常に複蜼な形態のテステは術後に形 成されたものであると考えられる。

私の症例仁認めた粘膜テステの成因を総括すると大略 3型に分ける事ができる・即ち，

第 1 型：粘膜の乳嘴状突起部の尖端が 互に相接し， その部の上皮が脱落して療着し 根部にキステを形成す る.

第 2 型：粘膜凹楩の表面に近い部分が 狭嫁乃至渝着 して潹部がデステとなる。

第 3 型：遗残粘膜が周囲から増殖した肉芽の内に埋 没してチステを形成する。

6) 腺チステについて

慢性中耳炎の中耳粘膜にみられるキステを始めて記載 した Politzer ${ }^{40)}$ (1878) は粘膜深層にあるものについ ては，これを淋巴管チステであると述べている・しかし その後 Habermann ${ }^{11)}$ (1889) が淋巴管テステを否定 して以来，殆で全ての交献には粘莫上皮から形成された 粘膜テステとしてのみ記載されている・唯 Habermann のみはテステの形熊から腺テステであろうと主張した が，彼自身す中耳粘膜には腺を欠如する事からこれにつ いて断定を下寸新は危険であると述べている。

Goerke 8)(1901) は耳耳茸に赫いて色々な形の管状腺 が存在するが，それは円柱上皮の凹宿から二次的に形成 されたものであるとして䞑りこれに柌して Grünberg 
๑)（1917）は二次的に腺が形成される事について性疑閣 の余地があると述べている。

正常中耳粘膜に扔汗る腺の存在については多くの議論 があり；Katz ${ }^{18)}$ 全書によると Kessel, Bulle, Siebnmann, Preysing, Luschka, Sappy, Brunner 等は腺の 存在を否定し, Tröltsch, Politzer. Wendt u. Krause 等は鼓安前方の耳管入口部に少数の腺があると主張して いる. 叉 Möllendorff ${ }^{33)}$, Jordan'77), Maximow \& B1Dom 32), Bargmann ${ }^{3)}$ 等の組織学成書には 腺を否定し ているが, Rauber Kopssch ${ }^{43)}$, Cowdry 7), Stöhl 等 には耳管入口部に小さい腺が稀に存在する事があると述 ベてある・

従つて中耳の大部分並びに 乳突部粘膜には腺を欠く が，鼓室の耳管入口部には腺の存在が考えられる. 従つ て耳管入口部に䞌いては腺チステ形成の可能性が考吝ら れるが，今日迄耳茸を除いては，中耳糊膜に腺テステを 証明して報告はない。

私住 16 例中 1 例（第 5 例，㝍真 20) の鼓室前方に腺 チステと思われるむのを発見した・即ち，単管状腺で単 層瀻毛円柱上皮认被われた導管を有し，粘液性腺管之円 柱形上皮細胞に被われる腺管とからなり，深部の腺管は チメテ樣に膨大し，内膑には腺上皮細胞が脱落して互に 融合し上皮性巨細胞を形成する移行像を認めた。しかし 私の標本では極めて病变が 強いので，腺管の分岐の壮: 熊, 尊管の形態等を詳細に究める事はできなかつた。こ の点に関しては今後更に追究してみたい．

7）骨変化の意義について

所謂骨病变のために表皮化が妨け゚られ，排殓をきたす と云う事は特に我国に特いては広く信じられている・し かしながら交献を考察してみると，骨病変のために表皮 化が游げられ，治瘉しない專実を組織学的に明暸に証明 し得た報告は全く見当らない。

Brunner 5) 6)（1931，1954）は根治手術後の術創で円 柱上皮と表皮が混在し，強、化膿性炎症のある部の下の 骨には全く変化なく，かえつて正常な表皮に被われた部 分の骨壁に骨炎及び稀であるが破骨細胞を諗めて扣り， 術創の排膿と骨とは全く無関俰であると述べている。

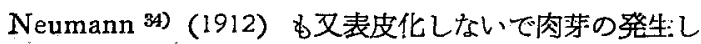
ている部位に Osteoporose（著者註, Osteolyse の所見 に近い）を証明しているが，一方長期間表皮化して治痖 していた部位にもその表皮下に Osteoporose を証明し ている.この事は逆に Osteoporose の如竟激しい骨病
変があっても表皮化は娃げられるものではない事を示し ている・まてて慢性中耳炎の骨変化について友ると，最 近の吉田 ${ }^{57)}$ (1957) の報告にも明らかなようと, 最も多 く見られる変化は一般に治癁㙨転とみなされている骨新 生であつて，しかむ造骨細胞の消失した静止形のもの で，稀に骨吸収像が見られるに過ぎないと云う・果して この程度の骨変化によつて治滑が阻害されるるのか䃌か は未だ明らかにされていない，少くとも病理学的な立場 からは疑問の多いとこらである。

一方 Mann 27) (1912) は敢管入口部の治癒し難いの は耳管開放のためではなく，耳管壁の骨炎のためである と述べたが，Wittmaack はこれに対して，骨のカyェ スは粘膜の炎症に伴う二次的変化であつて, 粘膜面が表

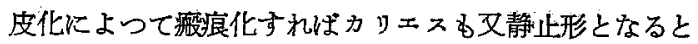
述べて反論している。

仁保（正)，石川 16）（1951）は根治手術を受げたが治 らなかつた 1 例洅手術を行つた経験を報告し，病巣部 は慢性骨炎，骨噵炎とその急性増悪の所見であつたと し，根治手術後の排膿の原因は耳管開口部を除外すれぱ 残存せる慢性骨炎加ら産生されると述へている・しかて この症例は生後 3 年で中耳炎発症後 11 月, 前回手術後 1 月しか経過していない特殊性を考えると，これをむつて 臨床上縻々遭遇する術後性慢性中耳炎の全ての病巣につ いて結論を下す孛脃険であると考えられる・一方仁保 （三），吉尾 ${ }^{36)}$ (1952）は根台手術後の 5 例錐体手術を 行い，全例に肥大堌殖した立方上皮に被われた含気蜂栄 の遗残を認めたが，骨について 5 例中 1 例に资泟性骨破

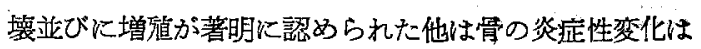
少いと述べている.

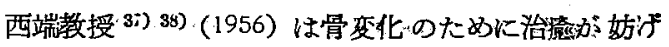
られる事があるが，この骨变化とは骨吸収王は骨絧胞消 失程度のものであって，一方このような骨変化があっ も表皮化は必ずしも妨げられるものではないと述べてい る. 恐らく粘膜遺残の有無によつてこのような相違が生 ずるのではないかと考えられる・

Krebs 21) (1912) は一旦治癒した術創の骨壁が数年後 に血管の乏しい外皮に被われるために栄荃障碍を起し， これに二次的誘因が加かつてカリェスとなり（Sekundäre Karies)，溃瘍を形成すると述へている.このよう な術後に生じた新しい骨变化については Stacke 46), N2umann ${ }^{34)}$ 及び Brunner 5) 6) む速べて抹り, Brunner は特に乳㥆洞天蓋と水平半規管に肉莱増生のための骨赫 
装を㒛めているが，破骨細胞を認めず静止形となつてい

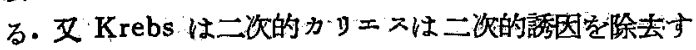
れば急速に治療すると述ベており，これらが長期間表皮 化を妨げて排脤の原因となり得るとは考えられない。

翻つて考えるに，根治手術創が骨变化のために治瘉し 得ないと云う事を推諭するためには，少くとす術後性中 耳炎の病单部に病的粘膜の遗残のない事を先ず証明しな はればならない.私が 49 例の術後性慢性中耳炎の中か ら、手術がかなり徹底して行われているのに治らない15 例について組織学的に詳細な検索を行らと，全病巣部に 例外なく病的粘膜を認め，それが排膿源となり表皮化を 阻止している事を確認した・文病坚下の骨を組織学的に しらベたが，一部に軽度の骨新生像を認めるのみで著る しい病変を認める事はでさなかつた・更にその病巣㑔部 組織を除去する事によつて，12 例は完全に沿癒したが， 残余の 3 例はいずれも正円空窩附近のみが治疾しないの で，その部の粘慕除去が充分でなかつた帚が考えられ る.

㕛残る33 例について再手術時の臨床的所見をみてる， 全て病的粘膜又は遗残䗋巣を認めている。即ち，私の 49 例の術後性慢性中耳炎では，骨変化のために治㽷し得な いと思われるものは1例もなく，全て病的粘膜の遗残又 は術後伸展せる耳管粘膜の炎症が治㾍を妨げる最大の原 因である事を砤認した・そして，この事は前章に述べた 122 根治手術例に和ける難冾部位の 統計的観察とも一致 するあのである。

$$
\text { IV 結 ‥ 語 }
$$

1) 慢性中耳炎 112 例，122手術例（内再手術 49 例） に扗、，完全に表皮化したもの（完全治痖）76 例 $(62.3$ $\%$ ，不完全表皮化のる（不完全治涂）46 例であつた.

2) 耳管入口部の処置と治滖との関係は，耳管入口部 のみを掻爬したものは50\%，Mayer 法を行つたものは $75.8 \%$ の治䢔率大示した・

3) 不完全治癒例の難治部位は乳突部 $14.6 \%$, 鼓至周 辺部 $85.4 \%$ であつた・乳突部では迷路周囲部が最も多 く，鼓室周辺部では鼓室後方，耳管人口部，下鼓室の順 『多からた・それ故錐体尖部の病紧遺残のための難治例 は僅少と思われる。

4）術後性慢性中耳炎 49 例に再手術を行つた際，大 部分の病紧部に肉眼的に病的蜂巣又は病的粘膜の遗残を 琶めた。

5）上記 49 例の内からある程度根治手術が充分に行 われているにす拘らず，術創が治痖していない症例 15
を選び，その病坚部の病理組織学的倹索を行つた・

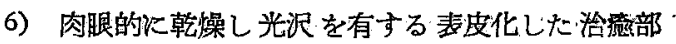
は，組䢂学的にもはડ゙完成した外皮に被われている・し

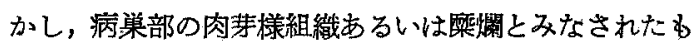
のは全て組織学的には，慢性炎症あるいはこれに急性增 悪を伴ら病的粘膜であつた.そして肉哏的に術創の表皮 化が停止している部位では，病的粘膜のために表皮の伸 展が阻止されている事を知つた。

7）これ等の病巣部を再手術によつて取除いた緄果， 15 例中 12 例は完全に表皮化して治癒した・治癒しない 3 例の未治部位はいすれれる正円空䉥附近である・即ち， この部位の粘膜を除去する事は極めて困難である・

8） 15 例中 4 例の病巣下の骨を検索した結果，骨新 生像のみで病的の吸収像及び 壊死像を全く認めなから た。

9）以上の所見から，15例の全病巣部に和いて，表皮 化を阻止し排呩を持続するものは资症性粘膜乃至炎症性 粘膜に基ずく病的肉芽の堌生のためであつたと考えられ る・一般に強調される説に反して, 病巣部の骨は必ずし も術創の表皮化を妨げる因子とはならない。

10）術創に存在する病的粘膜を形態によつて9型に 分類した。

11）病的粘膜に認めた最も著明な所見はチステ並び に凹樎の形成である。

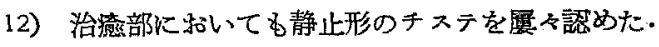
根治手術後の術創が治漓するためには，不可避的な遗笺 粘膜は表皮下にチステとして包埋されるか, Hohlraum を形成して耳管へ通ずる事が必要である・

13）15例中 1 例に鼓空腺を認めた・

\section{V 引用文献}

1) Arey, L.F.: Wound healing. Physiol. Rev. 16: 331, 1936. 2) Eánhidy, F.u. Fodor, F:: Operationsresultate der chronischen Mittelohreiterung ohne Cholesteatom. Mschr. Ohrenheilk. 90: 129 134, 1956. 3) Bargmann, W.: Histologie u. mikroskopische Anatomie des Menschen. Bd. 2, S. 686, 1956. 4) Brock, W.: Handbuch d. H.N. Oh. von Denker u. Kahler. Bd. 7. S. 214 220, 1925. 5) Brunner, H.: Über das Verharten d. Mittelohrschleimhaut nach. Radikaloperotionen. Arch. Ohr.,, Nas.", u. KehlkHeilk. 128: 28〜68, 1931. 6) Brunner, H.: Changes in tympanic cavity and antrum resulting from radical mastoid operation. 
Arch. Otolaryng, Chicago. 60:655 676, 1954. 7) Cowdry, E.: A textbook of his tology. p.421 422, 1938. 8) Goerke, M.: Pathologisch-anatomische Untersuchungen Von Ohrpolypen. Arch. OhrHeilk. 52:63 109, 1901. 9) Grünberg: Hand. buch d. pathologische Anatomie d. menschlichen Ohres von Manasse. S. 91, 1917. 10) 後藤敏唰:

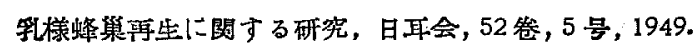
11) Habermann, J:: Zur Entstehung des Cholesteatoms des Mittelohrs (Cysten in des Schleimhaut der Paukenhöhle, Atrophie der Nerven in der Schnecke). Arch. OhrHeilk. $27: 42 \sim 50,1889$. 12) Hajek: Heiss, R. 可用. Handbuch der mikroskopischen Anatomie des Menschen von Möllendorff. Bd. 5 3, S. 721,1936 . 13) Hampman, J.A.: Surgery of suppuration after radical mastoidectomy. J. Laryng. 62: 435 439, 1948. 14) Henius, P.U. Schousboe, H.I.: Untersuchung betreffend die Dauerresultate der Totalaufmeisselung des Mittelohres. Acta otolaryng. Stockh. 6: 138 144. 1924. 15）堀口伸作：慢性蝶焱根治手衡所見, 日 耳会, 60:582,1957。16）石川実, 仁保正次：側頭

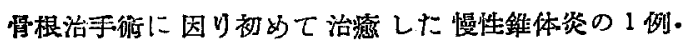
耳喉, 23:6, 1951. 17) Jordan, $E .:$ A textbook of histology. p. 594, 1934 . 18) Kantz u. Walter: Die Ausheilung der Wundhöhlen nach Radikaloperationen des Ohres. Z bl. Hals-Nas.-u. Ohrenheilk. Bd. 30, 1938. 19) 狛島逹雄, 五十䬑真：根 治手術後の考察について，日耳会，57：1047，1954. 20）北川高久，高楅照明：人の健常並に病的虫垂にお ける.Paneth 氏細胞亚に゙杯細胞の研究，日組錄，14： 329. 1958. 21) Krebs: Über sekundäre Karies nach Attikoantrotomie. Verh. dtsch. otol. ges. 21 : 268 273, 1921. 22) Lange, W.: Über den Heilungsverlauf und die Dauerheilung nach Radikaloperation des Mittlohres. Beitr. Anat. \&c., Ohr. 3: $170 \sim 216,1910 . \quad$ 23) Lange,.: Über die Heilungsvorgänge nach Antrumoperation. Beitr. Anat. \&c. Ohr. 4: 1 25, 1911. 24) Laurowitsch: Tubenverschlu $\beta$ bei Radikaloperation. Verh. dts= ch. otol. Ges. 21 : 258 263, 1912, 25.) Lieschke: Ergebnisse der Epitheltransplantation nach Thiersch in Radikalhöhlen. Z. Hals-Nas.-u. Ohrenh- eilk. 2 : 137, 1950. (Zbl. 4l, 1950 51). 26) Lempert. J.: Modern temporal bone surgery, histol ogy its evolution. Laryngoscope, St Louis Vol. 60, No. 8,1950. 27) Mann: Verh. dtsch. Ootol. Ges, $21: 264,1912$. 28) Mahn, W.: Ũber die Heilung Von Radikaloperationshöhlen. Z. HalsNas.-u. Ohrenheilk. $43: 226,1938.29)$ Manasse, P.: Handbuch d. pathologische Anatomie d. m.. enschlichen Ohres, S. 44, u. S. 54, 1917, 30) Marx, H.: Handbuch d. Ohrenheilkunde S. $27 \mathrm{k}$ 〜284, 1938. 31) Mayer, O. u. Beyer, H.: $40 \mathrm{Ja}$. hre Radikaloperation. Z. Hals-Nas-u. Ohrenheilk24 : 74, v. 148, 1929. 32) Maximow and Bloom: A textbook of histology p. 609, 1934. 33) $\mathbf{M o ́}^{\circ}$ llendorfl: Handbuch d. mikrospopischen Anatomie des Menschen. Bd. 3, S. 261; 1927. 34) Neumann, H.: Zur Klinik und Pathologie alter Radipaloperationshöhlen. Z. Hals-Nas.-L. Ohrenheilk. 24 : 379, 1929. 35) 保三四次, 杗尾克已 :

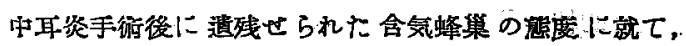

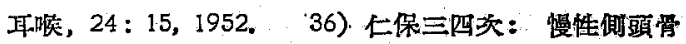
炎に対する䤵体手衙 100 例の経験，耳喉，52：213， 1953. 37) Nishihata, T.: Radical surgery on os temporale, a study based on newer concept of pathological changes in infection of temporal bone. Arch. Otolaryng., Chicago. 62: 586, 1955. 38) Nishihata, T.: Transition of the concepts in otitis media. Keio Journal of Medicine. $6: 21$, 1957. 39) Ohrt, H.H.: On reccurence in cavities. after radical mastoidectomy with special refere. nce to the complications which may arise. Acta Oto-laryng. (Stockholm). Vol. 47, No, 4, 1957. 40) Politzer, A.: Zur patholgoischer Histologie: Mittelohrauskleidung. Arch, Ohr Heilk. 11:93. 29, 1876. 41) Preysing, H.: Handbuch d. spe-: zieller Chirurgie d. Ohres u.d, oberen Luftwege. von Katz u. Blumenfeld. Bd. 2, S. 225, 1925. 42), Rambo, T.: Factors affecting healing following. temporal bone surgery. Laryngoscope, St Louis. 66: 810 845, 1956. 43) Rauber Kapfsch: Lehrbuch und Atlas der Anatomie Bd. 6, S. 541, 19.23 . 44) Reinking, F.: Über die Ausbreitung des Schleimhautepithels auf die Wundflächen nach 
写 真 1

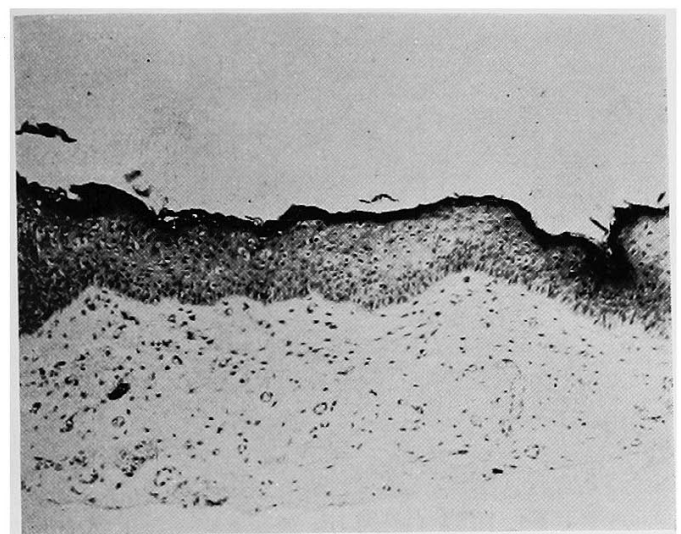

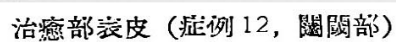

写 真 3

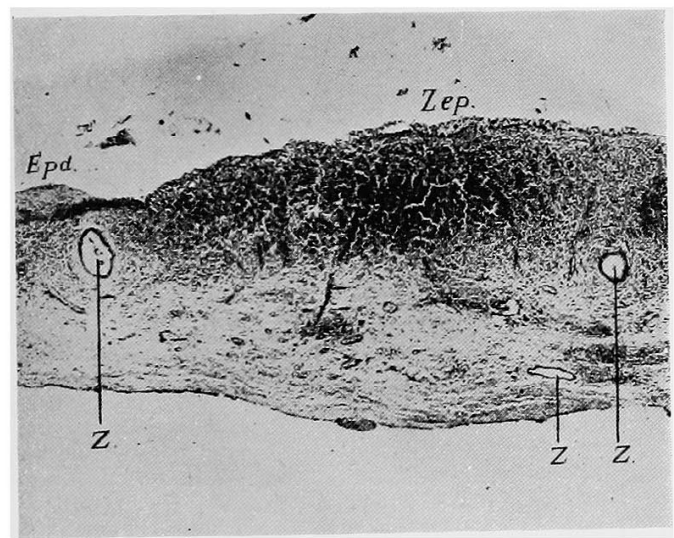

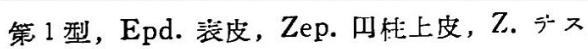
$\bar{\tau}$ (䔫例 1 , 鼓室後方)

\section{写 真 5}

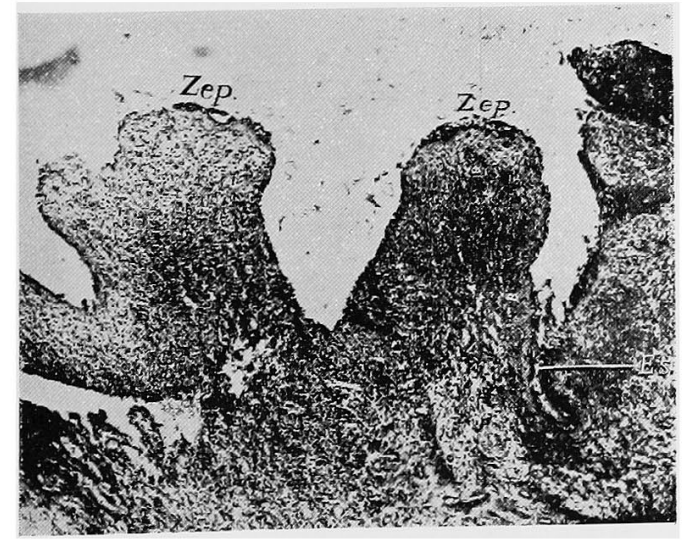

第 2 型 $\mathrm{b}$, 乳嘴状突起の間に形成された凹陷 (Es.),

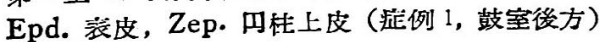

写 真 2

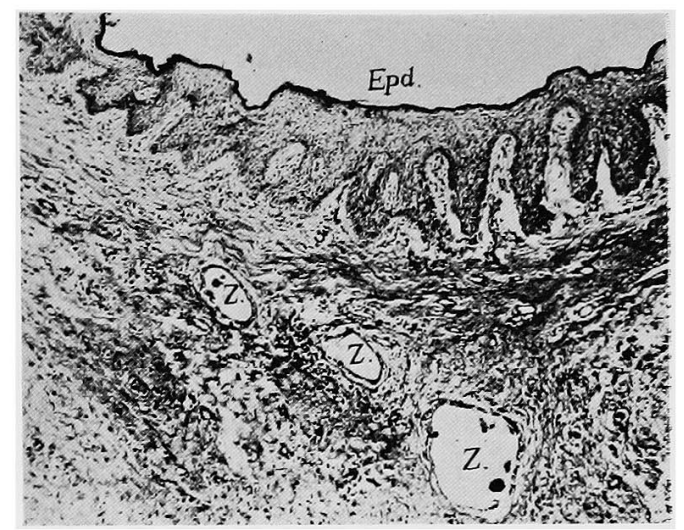

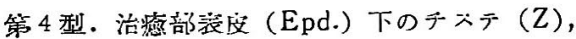
（拜冽 15 , 鼓室)

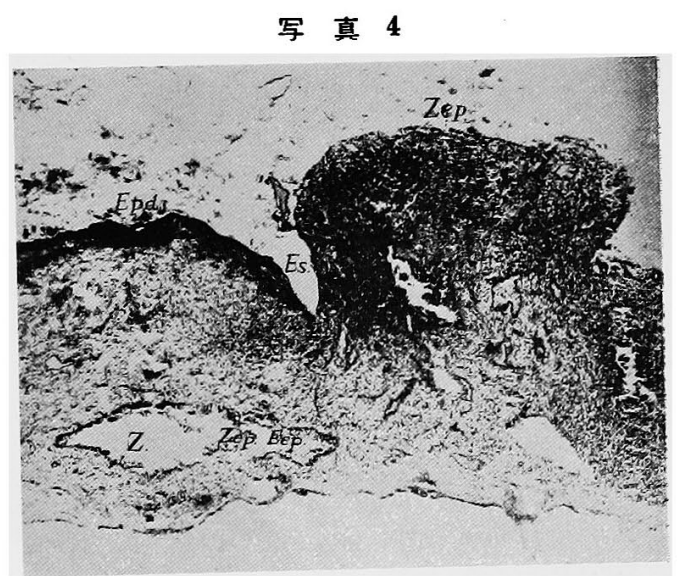

第 2 型 a 並びに管 3 型 $\mathbf{c}$ ，凹陷（Es.）上り形 成されたチステ (Z.), Epd. 㠇皮，Zep. 円性 上皮 (䇥冽 1 , 鼓至得

写 真 6

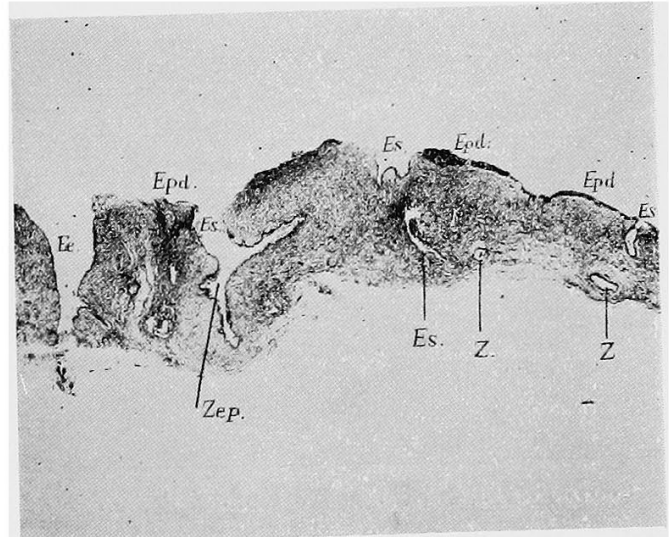

第 3 型 b，Epd. 䒾皮，Zep. 凹仕上皮，Es.凹 陷，Z. チステ (还例 9，下跂室） 
写 真 7

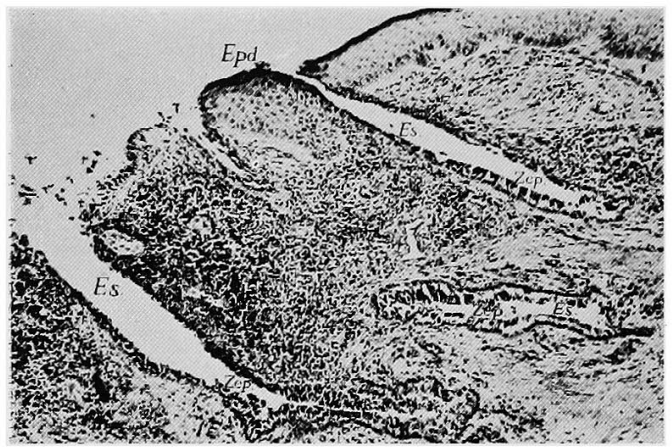

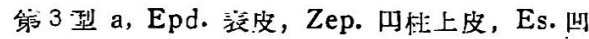
陷 (正列 12, 鼓室)

写真 9

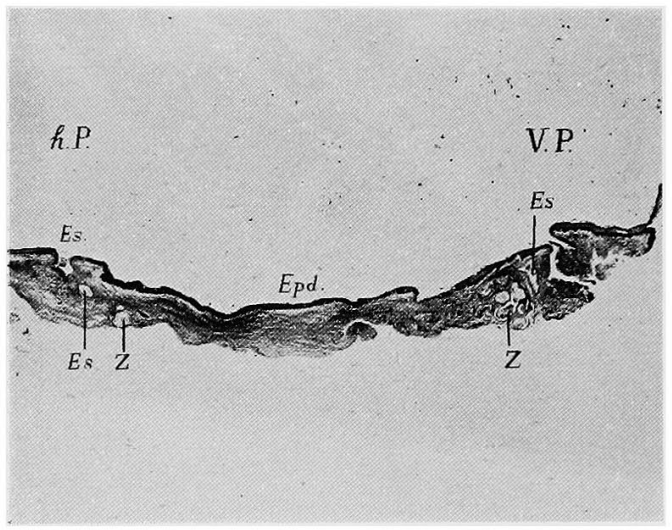

第 3 型 a, b, c 並びに第 4型, v.P. 鼓室前方, h.P. 鼓室後方，Epd. 翣皮，Es. 四陷，Z. 千 ステ（狱例 6 ，鼓窒）

写 真 11

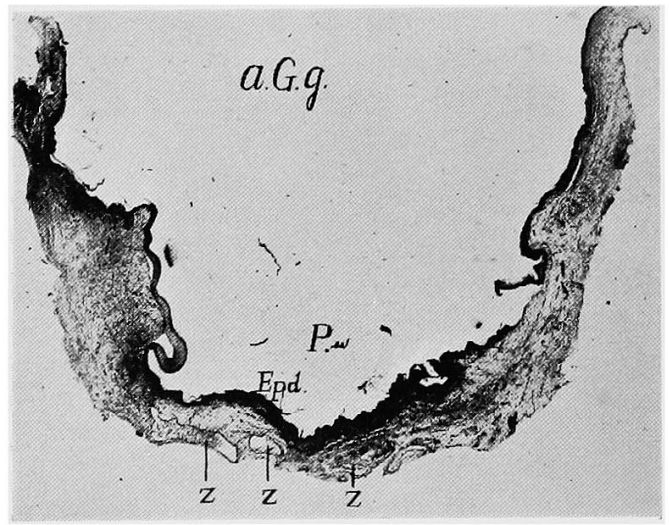

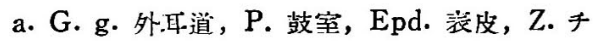
ステ（䇤例 10, 鼓空から外耳道にかけて）
写 真 8

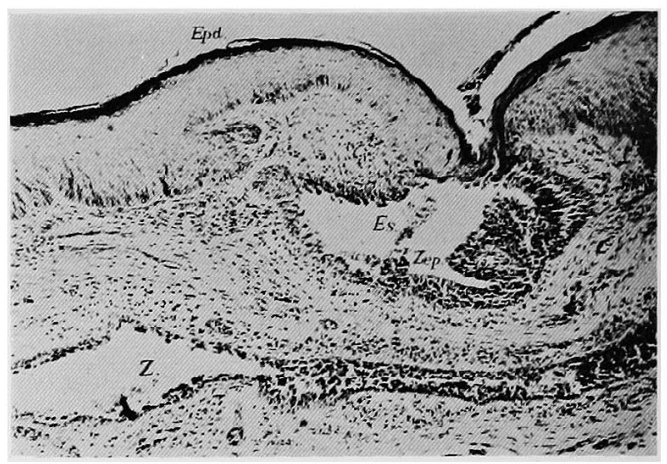

第了型 c, Epd. 言皮，Zep. 四生上皮，Z．テ ステ，Es、陷（证例 12, 鼓室）

写 真 10

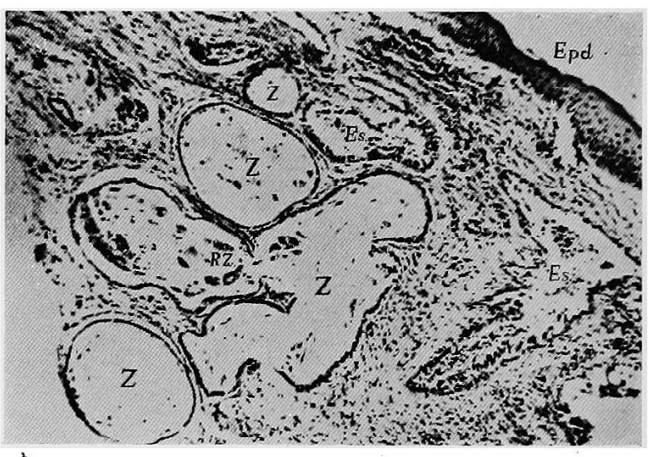

Epd. 䓂皮，Es. 凹陷，Z. チステ，Rz. 巨洲胞 （同前，鼓宝站方の搪大図）

写 真 12

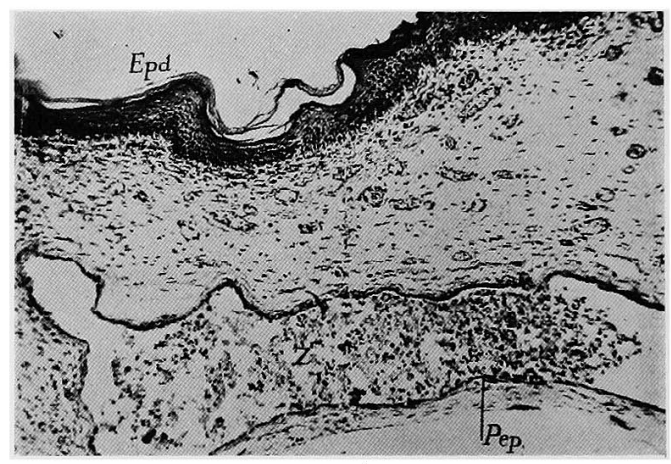

Epd. 坟皮，Pep. 病平上皮，Z.テステ（同前， 鼓室の一部拡大） 


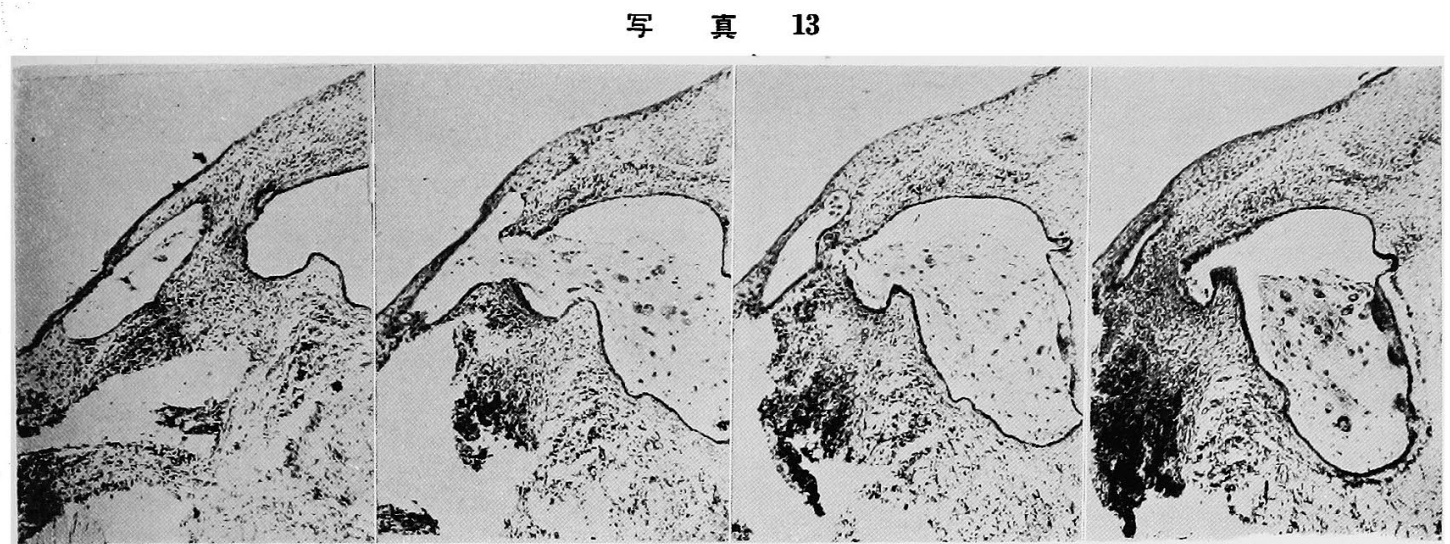

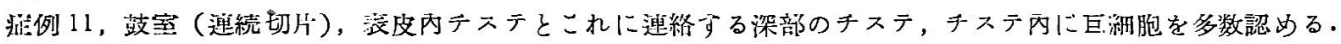

写 真 15

写 真 14

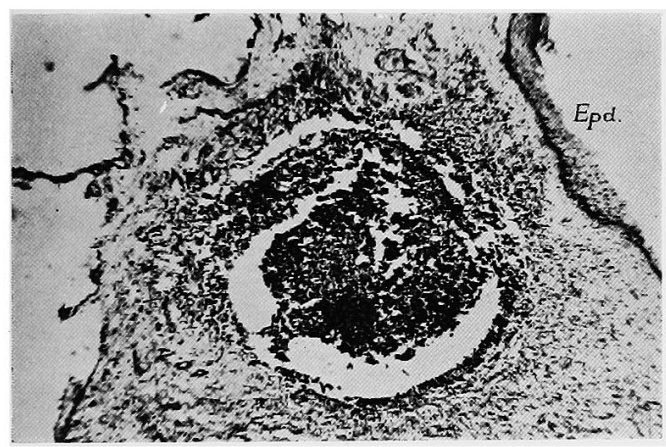

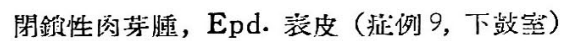

写 真 16

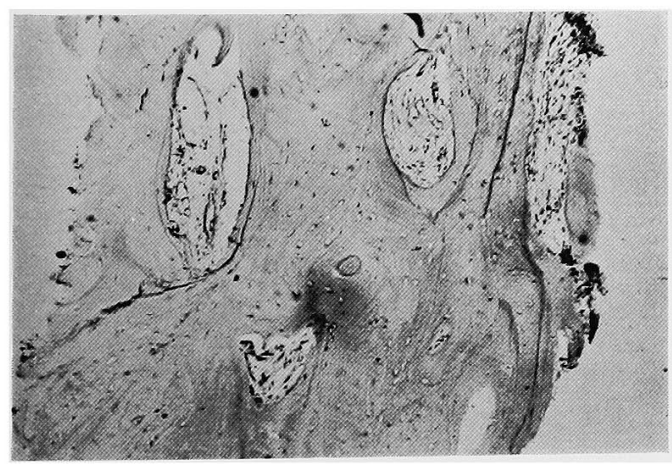

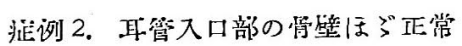

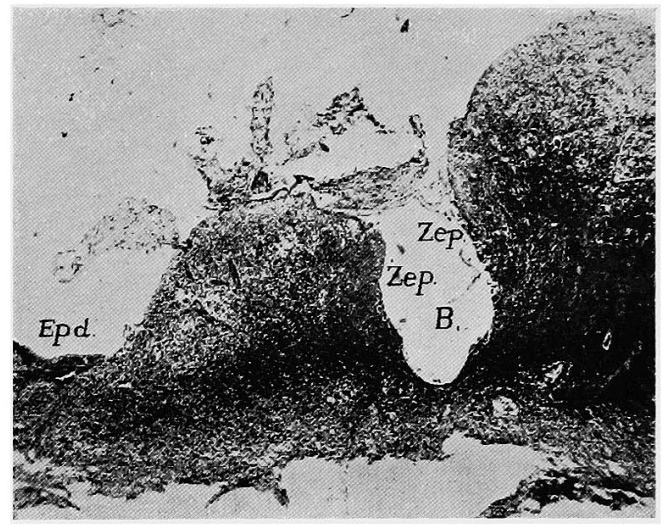

開放性闪芽腫，B. 湾入部，Epd. 核皮，Zep. 四

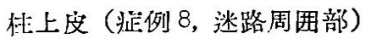

\section{写 真 17}

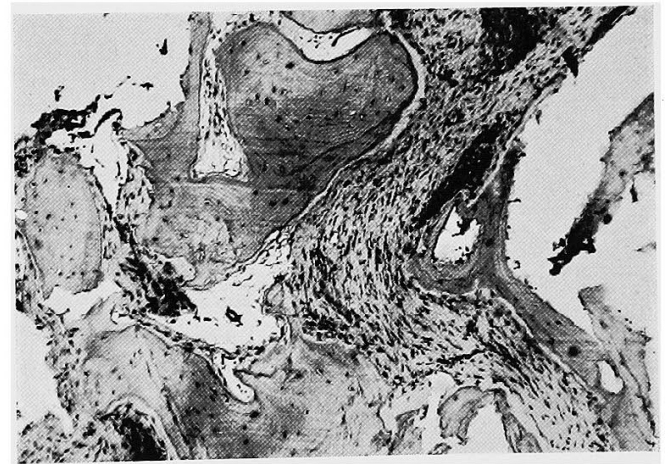

㱜例 7，下㪗室の管壁

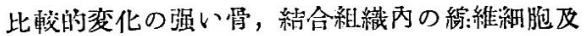

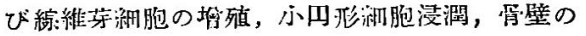
Umbau, 督坦殖像 
写 真 18

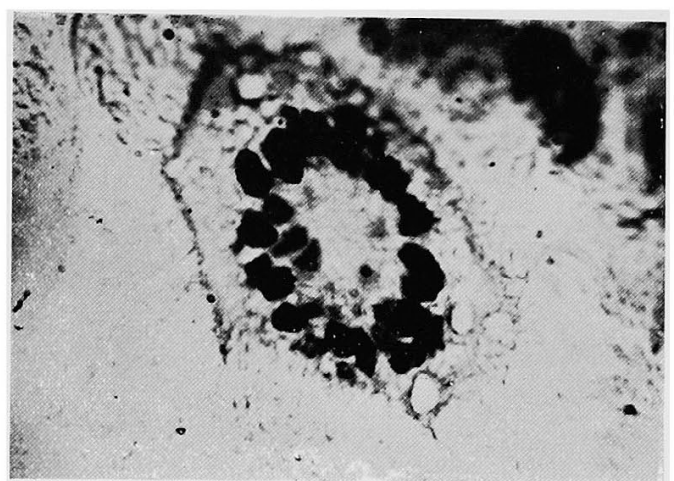

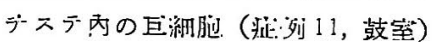

军 眷 20

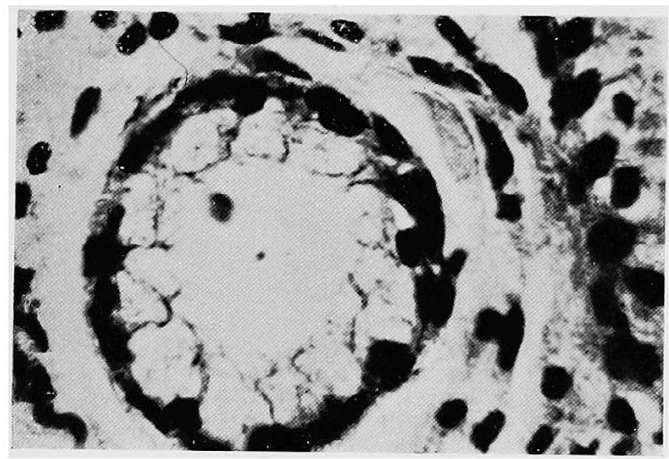

豉空腺 (症冽 5 , 跂空)

写 真 22

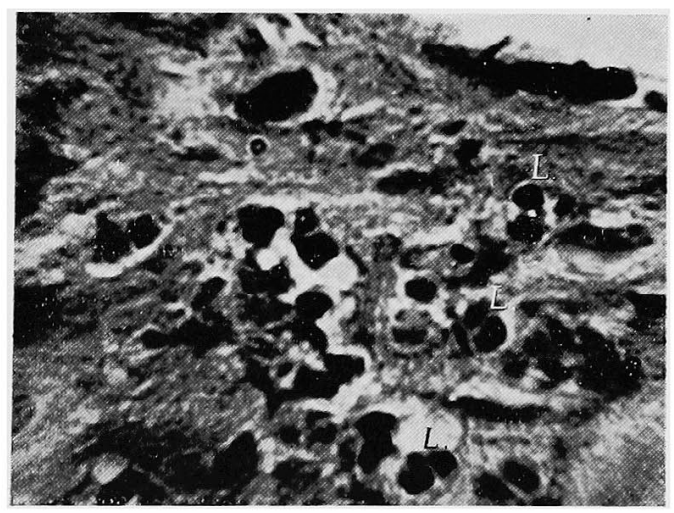

表皮內を遊走する多核白血球 (L.)（症例 5, 迷 路周囲部)
军真 19

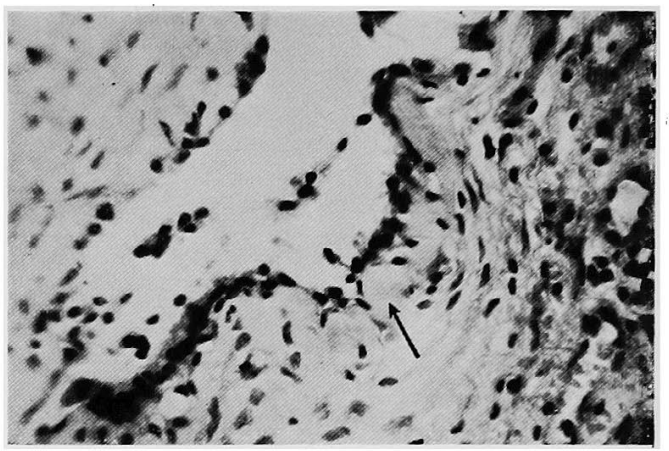

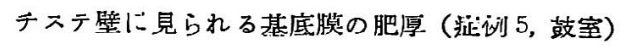

\section{写 真 21}

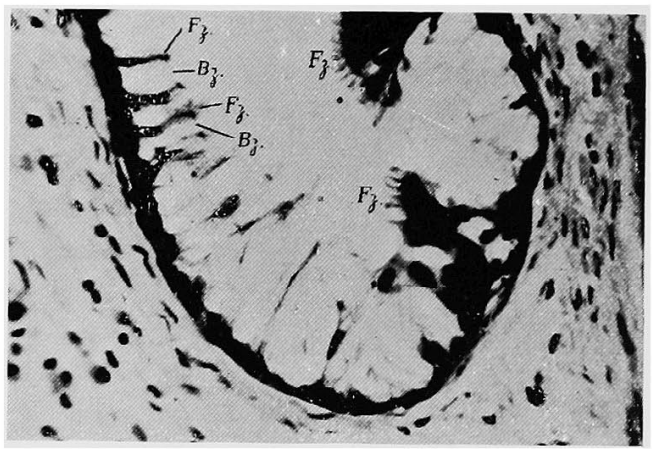

凹陷に認如られた杯細胞（Bz.）とこれに圧迫 された繊毛上皮細胞（Fz.）（症例 11 ，鼓室）

写 真 23

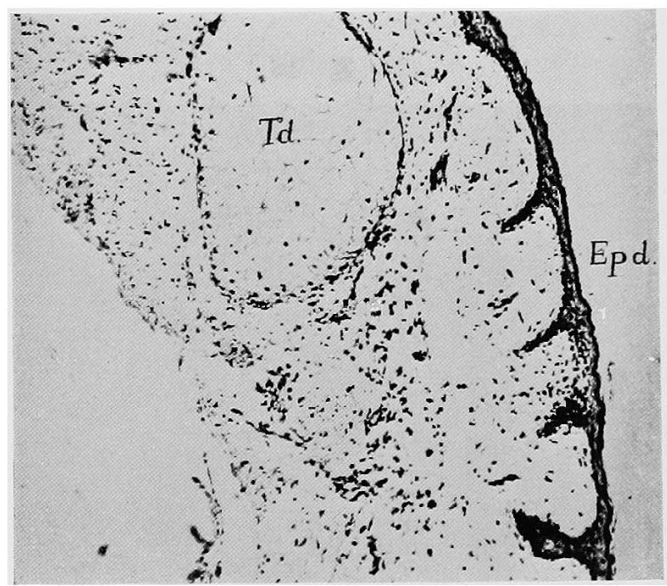

悯巢周辺部に゙認められた皮脂腺（禃皮によつて 移入されたもの) Epd. 兖度, Td. 皮脂腺（症 例 8 , 迷路周囲部) 
Operationen am Mittelohr. Z. Ohrenheilk. 54 : 311 321, 1907. 45) Ruttin. E.: Histologische Studien über die Veränderungen der tympanalen Labyrinthwand bei radikal operierten Fällen chronischer Mittelohreiterung, Arch. Ohr Heilk. 76: 81 94, 1908. 46) Stacke: Über eine Methode der Plastik zur Deckung der operativen Fr. eilegung der Mittelohrräume entblössten Knochenflächen. Verh. dtsch. otol. Ges. 4: 83 91, 1895. 47) 鈴木安恒，川島迋雄，岡野贫子：中耳根治手床直 後に行う简単な植皮法，耳崌，25：364，1953.48) 高

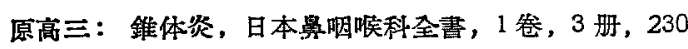
頁. 49) Temkin, J.: Erfahrungen mit primären Hauttransplantationen der radikaloperierten $\mathrm{Mi}$ ttelohrräume. Z. Hals-Nas.- u. Ohren-heilk. 22 : 467, 1929. (Zbl. 14, 1930). 50)Tepsen, O. u. Zwergius, E.: The cavity after retroauricular radical ear operations with special refference to the significance of the primary factors. Acta Otolaryng., Stockh. Vol. 39, No. 5, 1951. 51) Thiess, F.: Die Radikaloperation durch den äußeren Gehörgang. Z. Hals.-Nas-u. Ohrenheilk. 33: 459 475, 1933.

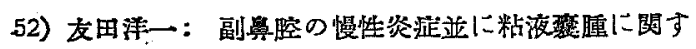
了実験的研究 第 2 編，日耳会, 61:548, 1958.53 ) 土由武正，中和和雄，提敏男：慢性中耳焱手衍後の僛頭 肯 2例, 耳喉, $28: 20,1956$. 54) Withalm, A.: Zur
Behandlung rezidivierender Operationshöhlen. Mschr. Ohrenheilk. 89: 103, 1955. 55) Wittmaack, K.: Zur Klinik, Komplikation und Indikation der Radikaloperation. Z. Hals.Nas.-u. Ohrenheilk. 1: 1 16, 1922. 56) Wittmaack, K.: Handbuch d. speziellen pathologischen Anatomie u. Histologie von Henke u. Lubarsch. Bd. 12, S. 110u. 216, 1926.57）占田正利：慢性中耳炎の管嗍理に関する 研究. 日年会, 60:582, 1957.58) Zeroni: Beitrag zur Kenntnis der Heilungsvorgänge nach der operative Freilegung der Mittelohrräume. Arch. OhrHeilk. 45: 171 185, 1898.

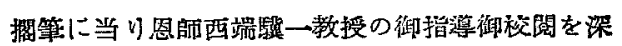
謝し，病理学教室堀江偡也講師の御教示に深甚の謝 澺を䒾します。

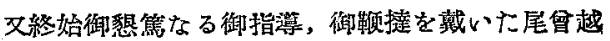
秀博士に心から感謝を捀げます。

なお，本研究に刘して昭和 31 年定文部省科学研 究費を交付されたことを感謝します。

本論文の要旨江日本耳㚜咽喉科学会第59 回学術 檴演会立びに関東地方会第352回例会に゙おいてロ演 レだ

（原稿到盖=炤和 34.2.23 日） 